University of Chicago Law School

Chicago Unbound

Public Law and Legal Theory Working Papers

Working Papers

2012

\title{
Children's Rights and a Capabilities Approach: The Question of Special Priority
}

\author{
Martha Craven Nussbaum \\ Rosalind Dixon
}

Follow this and additional works at: https://chicagounbound.uchicago.edu/public_law_and_legal_theory

Part of the Law Commons

Chicago Unbound includes both works in progress and final versions of articles. Please be aware that a more recent version of this article may be available on Chicago Unbound, SSRN or elsewhere.

\section{Recommended Citation}

Martha Nussbaum \& Rosalind Dixon, "Children's Rights and a Capabilities Approach: The Question of Special Priority" (University of Chicago Public Law \& Legal Theory Working Paper No. 384, 2012).

This Working Paper is brought to you for free and open access by the Working Papers at Chicago Unbound. It has been accepted for inclusion in Public Law and Legal Theory Working Papers by an authorized administrator of Chicago Unbound. For more information, please contact unbound@law.uchicago.edu. 


\title{
CHICAGO
}

Public LAW AND Legal THEORY WORKING PAPER NO. 384

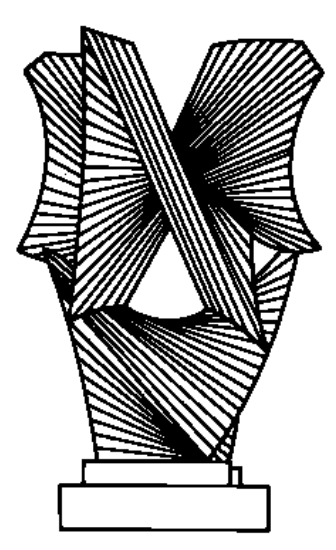

\section{CHILDREN'S RIGHTS AND A CAPABILITIES APPROACH: THE QUESTION OF SPECIAL PRIORITY}

\author{
Rosalind Dixon and Martha C. Nussbaum
}

\author{
THE LAW SCHOOL \\ THE UNIVERSITY OF CHICAGO
}

May 2012

This paper can be downloaded without charge at the Public Law and Legal Theory Working Paper Series: http://www.law.uchicago.edu/academics/publiclaw/index.html and The Social Science Research Network Electronic Paper Collection. 


\title{
CHILDREN'S RIGHTS AND A CAPABILITIES APPROACH: THE QUESTION OF SPECIAL PRIORITY
}

\author{
Rosalind Dixon† \& Martha C. Nussbaum††
}

The latter part of the twentieth century saw the near-universal recognition of the idea of children's rights as human rights. At the same time, the conceptual basis for such rights remains largely under-theorized. Part of the aim of this Article is to draw on the insights of the "capabilities approach" developed by Martha Nussbaum in philosophy, and Amartya Sen in economics, in order to provide a fuller theoretical justification of this kind. In addition, this Article investigates the degree to which it will be justifiable, under such an approach, for international human rights law or national constitutions, to give special priority to children's rights. It begins this task by first considering, and rejecting, potential justifications for such special priority based on the need to ensure the future self-reliance of children as adults and ideas about the special "innocence" of children; and, then, by developing two affirmative justifications for such special priority, based on the special vulnerability of children, and the special cost-effectiveness of protecting children's rights. This Article also explores the degree to which these principles may provide a starting point for thinking about more general trade-offs between different rights claims, or claimants, under a capabilities approach.

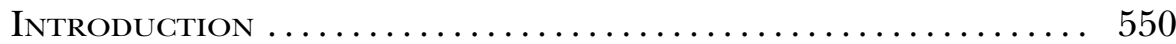

I. Universal Rights \& A Capabilities ApProach ......... 556

II. Special Priority for Children? ................. 565

A. Vulnerability Principle .................. 573

B. A Cost-Effectiveness Principle ............... 578

III. Limits \& Extensions ......................... 584

A. Limits ............................... 584

B. Extensions ........................... 587

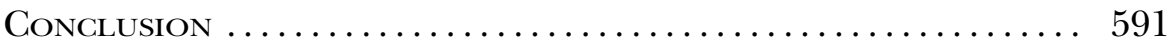

$\dagger$ Assistant Professor of Law, University of Chicago Law School; Senior Visiting Fellow, University of New South Wales Faculty of Law.

†† Ernst Freund Distinguished Service Professor of Law and Ethics, University of Chicago, Law School, Philosophy Department, and Divinity School.

Our thanks to Emily Buss and Aoife Nolan for helpful comments, and to Justin FoxYoung and Eliza Riffe for excellent research assistance. 


\section{INTRODUCTION}

A defining feature of the last century was the progressive expansion of rights to "people once ignored or excluded" by the law. ${ }^{1}$ A major milestone, in that process, was also the recognition in both international human rights (IHR) law and various national constitutions of the rights of children.

For much of the nineteenth century, children had few if any independent legal rights, let alone rights under international or constitutional law. ${ }^{2}$ This position was first challenged by leading enlightenment thinkers in the eighteenth century, ${ }^{3}$ and then at an international level in the early twentieth century, with the adoption by the League of Nations of the Declaration of the Rights of the Child. ${ }^{4}$ The movement for change gained further momentum in 1959, with the adoption by the U.N. General Assembly of a nonbinding declaration on children's rights, ${ }^{5}$ and in 1966, with the adoption of the International Covenant on Civil and Political Rights (ICCPR) and International Covenant on Economic, Social and Cultural Rights (ICESCR). ${ }^{6}$ The shift, however, was arguably only fully complete following the widespread adoption in 1989 of the Convention on the Rights of the Child (CROC). ${ }^{7}$

1 See, e.g., United States v. Virginia, 518 U.S. 515, 557 (1996) (noting that "[a] prime part" of the United States' constitutional history is the "story of the extension of constitutional rights and protections to people once ignored or excluded" (footnote and internal citation omitted)).

2 See, e.g., Barbara Bennett Woodhouse, The Changing Status of the Child, in THE U.N. Convention on the Rights of the Child: An Analysis of Treaty Provisions and ImplicaTiONS OF U.S. RATification 51, 52 (Jonathan Todres et al. eds., 2006) (explaining that nineteenth-century children were "subject to virtually unlimited parental authority" and that children's legal rights were "the mirror image of parental obligations").

3 See, e.g., 1 Adam Smith, An Inquiry into the Nature and Causes of the Wealth of Nations 28-29 (R.H. Campbell \& A.S. Skinner eds., Liberty Fund 1981) (1776) (stressing the importance of early education); see also infra notes 67-69 and accompanying text. For later thinkers in this same tradition, see Martha C. Nussbaum, Foreword, Constitutions and Capabilities: "Perception" Against Lofty Formalism, 121 Harv. L. Rev. 4, 8, 55 (2007) [hereinafter Nussbaum, Constitutions and Capabilities] (discussing the British political philosopher T.H. Green who supported various social legislation initiatives, including bills for free compulsory education); Diane P. Wood, Constitutions and Capabilities: A (Necessarily) Pragmatic Approach, 10 CHI. J. INT'L L. 415, 415 (2010) (exploring Nussbaum's view that "a society's constitution ought to include provisions designed to develop human capabilities").

4 Declaration of Geneva, League of Nations Doc A.107 1924 IV (1924).

5 See A. Glenn Mower, Jr., The Convention on the Rights of the Child: International Law Support for Children 13 (1997).

6 International Covenant on Civil and Political Rights, Dec. 19, 1966, S. Treaty. Doc. No. 95-20 (1978), 999 U.N.T.S. 171 [hereinafter ICCPR]; International Covenant on Economic, Social and Cultural Rights, Dec. 16, 1966, S. Treaty Doc. No. 95-19 (1978), 993 U.N.T.S. 3 [hereinafter ICESCR].

7 Convention on the Rights of the Child, Nov. 20, 1989, 1577 U.N.T.S. 3 [hereinafter CROC]; see also David Weissbrodt, Prospects for Ratification of the Convention on the Rights of the Child, 20 Emory Int'L L. Rev. 209, 209-10 (2006) (noting that CROC is the most quickly 
A similar pattern has emerged in many countries at a national constitutional level. In countries such as the United States and India, recognition of the rights of (equal) access to primary education for children began as early as the 1950s. ${ }^{8}$ In other countries, such as Honduras, Colombia, South Africa, and Brazil, more recent constitutions have included a range of express rights protections for children, including rights of access to education, basic nutrition, shelter, health (or health care services), social services, and social security; recreation (or sport); a name and a nationality from birth; and protection from maltreatment, neglect, abuse, degradation, exploitative labor practices, or other inappropriate or dangerous forms of work. ${ }^{9}$

At the same time, developing a theoretical basis for this increasing recognition of children's rights remains a work in progress. ${ }^{10}$

ratified human rights treaty to date and that since then "children's rights have come to the forefront of human rights").

8 See, e.g., India Const. art. 41 ("The State shall, within the limits of its economic capacity and development, make effective provision for securing the right to ... education ...."); Brown v. Bd. of Educ., 347 U.S. 483, 493 (1954) (noting that where a state or local government has chosen to provide education, it "is a right which must be made available to all on equal terms"). India's constitution came into force on January 26, 1950. Vijayashri Sripati, Toward Fifty Years of Constitutionalism and Fundamental Rights in India: Looking Back to See Ahead (1950-2000), 14 Am. U. InT'L L. Rev. 413, 416 n.7 (1998). For even earlier recognition of the right, see IR. Const., 1937, art. 42 (requiring the state to provide for free primary education and to require that "children receive a certain minimum education, moral, intellectual and social").

9 Constituição Federal [C.F.] [Constitution] art. 227 (Braz.) (calling it a familial, societal, and governmental duty to provide children with health and education and protect them from discrimination and violence); Constitución Política de Colombia [C.P.] art. 42 (stating that children born outside of a marriage, conceived with scientific assistance, or adopted have the same rights and duties as children born within a marriage or conceived naturally); Constitución Política de la República de Honduras, 1982, ch. IV, arts. 119-26 (detailing the rights of children); S. AFr. Const., 1996, § 28(1) (listing the rights of children, including the right to a name and a nationality). Other constitutions provide similar protection by implicit incorporation of CROC. See, e.g., E. TImor Const., 2002, $\S 18(2)$ (stating that children shall enjoy all rights "enshrined in international conventions commonly ratified . . . by the State"). East Timor has ratified CROC. See Child Rights CoAlition Asia, http://www.childrightscoalitionasia.org/southeast-asia/east-timor (last visited Nov. 13, 2011) (listing international human rights instruments ratified by East Timor). See further discussion in Aoife Nolan, Children's Socio-Economic Rights, DemOCRACy AND the Courts, at xxix-xxx (2011) [hereinafter Nolan, Children's SocioEconomic Rights]; Aoife Nolan, The Child's Right to Health and the Courts, in Global Health and Human Rights: Legal and Philosophical Perspectives 135, 142-44 (John Harrington \& Maria Stuttaford eds., 2010) [hereinafter Nolan, The Child's Right to Health].

10 See Martha Minow, What Ever Happened to Children's Rights?, 80 MinN. L. REv. 267, 287, 295-97 (1995) (noting progress in the international domain in recognizing human dignity as the starting point for children's rights, but also the degree to which the "movement for children's rights [has] failed to secure a coherent . . . intellectual foundation"). For more recent work, which begins to flesh out a dignity-based account with clear similarities to our own, see Michael D.A. Freeman, Upholding the Dignity and Best Interests of Children: International Law and the Corporal Punishment of Children, 73 Law \& Contemp. Probs. 211, 251 (2010) (arguing that "[t]o emphasize dignity is to engage with our conception of what it is to be human" and that it is now time to "recognize dignity's significance for children 
Many existing accounts of children's rights, for example, depend on a theory of children as "adult-like," or quasi-adults, entitled to the same rights and entitlements as adults under a social contract approach. ${ }^{11}$ Both CROC and many national constitutions, however, clearly recognize even very young children as enjoying various rights. ${ }^{12}$ Both IHR and many constitutions also omit certain key rights belonging to adults in the social contract tradition, such as the right to vote. ${ }^{13}$ While other theories focus more directly on the special needs and attributes of children, they also do so in a way that often fails to connect these special needs with an emphasis on children's agency. ${ }^{14}$

Part of the aim of this Article, therefore, is to provide a more fully developed theoretical account of children's rights, by drawing on the insights of the capabilities approach (CA) developed by Martha Nussbaum in philosophy and Amartya Sen in economics. ${ }^{15}$ A CA, this Article argues, provides a clear account for why children's rights should be recognized as human rights, because every human being, under

and for the corporal-punishment debate"); $c f$. David Archard, Children 160-70 (1993) (offering another alternative theory of children's rights, distinct from social contract ideas, based on notions of equality, democracy and "modest collectivism").

11 See Minow, supra note 10, at 275 ("Advocates for children use the rhetoric of rights . . to place children in the same legal position as adults ....").

12 See, e.g., CROC, supra note 7, at arts. 12-15, 24-28 (describing a child's right to freedom of thought and expression as well as a right to receive health and social services); supra note 9 and accompanying text.

13 See, e.g., U.S. Const. amend. XXVI. But see Minow, supra note 10, at 271 (describing John Holt's urging that children be given equal treatment under law, including the right to vote); see also Aoife Nolan, The Child as "Democratic Citizen": Challenging the "Participation Gap," 2010 Pub. L. 767, 768 (describing the lack of protection afforded to children's democratic participation as "deeply problematic"). One possible solution to protecting children's participatory rights would be amending the "franchise to introduce a weighted voting system, under which children are accorded a share of an adult vote which increases over time proportionate to the child's age." Id. at 777.

14 See, e.g., Martha Minow, Are Rights Right for Children?, 1987 Am. B. Found. Res. J. 203, 211 (reasoning that procedural solutions help children receive attention and "recognition of their distinct needs by those who have power over them").

15 See generally Martha C. Nussbaum, Frontiers of Justice: Disability, Nationality, Species Membership (2006) [hereinafter Nussbaum, Frontiers] (explaining that CA is a useful framework for exploring issues of social justice); Martha C. Nussbaum, Women and Human Development: The Capabilities Approach (2000) [hereinafter Nussbaum, Women and Human Development] (arguing that the best way to provide the basic social minimum that human dignity requires is to focus on each person's capabilities); Martha C. Nussbaum, Capabilities as Fundamental Entitlements: Sen and Social Justice, 9 Feminist Econ. 33 (2003) [hereinafter Nussbaum, Capabilities as Fundamental Entitlements] (discussing the relationship between Nussbaum's version of the approach and that of Amartya Sen); Nussbaum, Constitutions and Capabilities, supra note 3 (describing CA as entrenched in many parts of United States history and constitutional tradition). The entire related group of theories (including Nussbaum's and Sen's) is discussed in Martha C. Nussbaum, Creating Capabilities: The Human Development Approach (2011) [hereinafter Nussbaum, Creating Capabilities]. 
this approach, is entitled to respect for her full human dignity. ${ }^{16}$ Like other emerging theories based on the idea of human dignity, ${ }^{17}$ a CA also helps explain, in this context, why it makes sense for both CROC and various national constitutions to recognize a range of rights for children with sensitivity both to children's welfare needs and to children's agency.

Compared to theories in the social contract tradition, a CA also does better, we suggest, in accounting for the extension of rights to young children, and the denial of various rights to older children. By emphasizing the centrality of early childhood to the realization of a range of human capabilities, for example, a CA helps affirm the status of even very young as rights-bearers. At the same time, by emphasizing the idea of human dignity as a touchstone for IHR and constitutional law, a CA also helps ground children's rights in a way that potentially justifies limits on children's political rights, such as the right to vote, in some national and historical contexts. For these reasons, although theories of the social contract remain extremely valuable and give us deep insight into justice, we argue those interested in theorizing the entitlements of children should prefer the CA.

The account of children's rights provided by a CA, in this context, has important similarities with that provided by Nussbaum in support of the rights of persons with intellectual disabilities. ${ }^{18}$ At base, the argument for recognizing both sets of rights rests on a very simple idea about the moral claim of all human beings to be afforded full human dignity, regardless of their capacity for rational or reasoned participation in public or civic life. In both cases, the recognition of such rights can also imply a corresponding duty on the part of the state to provide extensive forms of affirmative protection for individuals.

At the same time, this Article suggests, in certain contexts both CROC and various national constitutions also give special priority to the so-called "welfare" or "socioeconomic" rights of children over those of other groups in society in a way that seems far less easy to

16 This also accords with the basis given for recognizing children's rights under instruments such as CROC. See, e.g., CROC, supra note 7, pmbl. "'Bearing in mind that the peoples of the United Nations have, in the Charter, reaffirmed their faith in fundamental human rights and in the dignity and worth of the human person, and have determined to promote social progress and better standards of life in larger freedom . . ..").

17 See, e.g., Freeman, supra note 10, at 251 (stressing the importance of emphasizing human dignity).

18 See Nussbaum, Frontiers, supra note 15, at chs. 2-3; Martha Nussbaum, The Capabilities of People with Cognitive Disabilities, in Cognitive Disability and Its Challenge to Moral Philosophy 74, 79 (Eva Feder Kittay \& Licia Carlson eds., 2010) [hereinafter Nussbaum, The Capabilities of Persons with Cognitive Disabilities] (arguing that "it is the equal dignity" of human beings that demands recognition). 
justify from the perspective of a CA. ${ }^{19}$ A CA certainly recognizes the potential for different kinds of rights to conflict, and thus also the need to impose limits on some individual rights in order to protect the rights of others. ${ }^{20}$ This also explains why a CA sanctions the idea of imposing limits on parental rights and freedoms, in order to protect the future rights or capabilities of children.

Absent such direct conflict between the rights of children and adults, however, a CA is generally committed to the equal protection of rights for all up to a certain minimum threshold.21 Any trade-off that leaves some people below this threshold will thus be a clear failure of basic justice under a CA, which should prompt a search for long-term strategies that will bring all citizens above the threshold. CROC and various national constitutions, however, clearly give at least some degree of special priority to the realization of certain rights for children, without in any way marking out this trade-off as "tragic."22

A second key aim of this Article, therefore, is to provide a careful examination of when, if ever, this kind of special priority to children's rights can be justified from the perspective of a CA. It identifies two broad potential justifications for the grant of special priority to children's rights in this context: first, where children are especially vulnerable as a result of their legal and economic dependence on adults, as well as their inherent physical or emotional vulnerability (a "vulnerability principle"); and second, where the marginal cost of protecting children's rights is either so low that denying such a right would be a direct affront to their dignity, or where it is far more cost-effective to protect that right than an equivalent right for adults (a "cost-effectiveness principle"). By emphasizing the idea of spiraling capabilities needs, this second principle in particular also draws on prior work by Jonathan Wolff and Avner De-Shalit on notions of the "fertility" of particular capabilities, or "corrosive disadvantage" caused by certain capability failures. ${ }^{23}$

Neither of these principles of vulnerability or cost-effectiveness can, of course, be applied without careful attention to the particular national constitutional context. In every instance, the CA directs na-

19 For a thoughtful discussion of this issue more generally, see, for example, NoLAN, Children's Socio-economic Rights, supra note 9, at 238-39.

20 See Nussbaum, Capabilities as Fundamental Entitlements, supra note 15, at 44-46 (criticizing the absence of such a restriction in Sen's account of capabilities); Nussbaum, CreatING CAPABILITIES, supra note 15, at 71-74 (making the same argument).

21 For the concept of the threshold, see Nussbaum, Creating Capabilities, supra note 15, at 40-42 (arguing that the threshold expresses a minimum level for basic social justice and that it ought to be set aspirationally, although not unrealistically).

22 See, e.g., CROC, supra note 7, at pmbl. (emphasizing that children are entitled to special assistance).

23 Jonathan Wolff \& Avner De-Shalit, Disadvantage 133-34 (2007) (exploring the distinction between "fertility functioning" and "corrosive disadvantage"). 
tions to make its abstract entitlements concrete in accordance with the nation's situation and history. ${ }^{24}$ Furthermore, its model of implementation draws on bill of rights jurisprudence in U.S. constitutional law, in which determinations of whether rights have been violated are made in individual cases against an evolving background of (always individual) precedents. In this tradition, highly abstract rights develop texture and specificity in an implementation process that extends over time, through confrontation with a wide range of particular cases. ${ }^{25}$

Each principle also has important logical limits. A vulnerability principle, for example, should be applied with careful attention to the potential common economic and physical vulnerability of children and adults, and to notions of what is reasonable to expect of parents in particular societies. Considerations of cost, by contrast, should not be allowed to obscure key differences between a CA and more utilitarian approaches, and thus should be applied with a close eye to notions of fertility and corrosiveness, and also limited to contexts in which there are actual resource constraints. In other cases, this Article notes, a defining feature of the CA is that it insists that individuals, such as those with severe cognitive disabilities, can legitimately expect far less cost-sensitivity from the state when it comes to the realization of their capabilities. ${ }^{26}$

Nonetheless, such principles do, we believe, provide a useful starting point for thinking about why it may be permissible for the state, in some cases, to give special priority to children, over adults, when it comes to the enjoyment of some rights. They may also, we suggest, provide a helpful starting point for thinking more broadly about when it will be permissible for a state to make trade-offs among different rights claims, or claimants, in a world of true resource scarcity. Proponents of a CA have to date approached this question by emphasizing that we ought to support capabilities that will best promote a long-term future of full capabilities, given the particular social and historical context. ${ }^{27}$ We flesh out this principle, however, by connecting it to notions of vulnerability, fertility, corrosiveness, and cost.

24 See Tom O'Neill \& Dawn Zinga, Introduction to Children's Rights: Multidisciplinary Approaches to Participation and Protection 3-18 (Tom O'Neill \& Dawn Zinga eds., 2001) (noting similar benefits to domestic efforts at implementation of CROC).

25 See, e.g., Dist. Attorney's Office for the Third Judicial Dist. v. Osborne, $129 \mathrm{~S}$. Ct. 2308, 2340 (2009), (Souter, J., dissenting) (elaborating on one view of the process by which courts in this tradition determine the "right moment . . . to decide whether substantive due process requires recognition of an individual right.").

26 See infra notes 57-58 and accompanying text.

27 See Nussbaum, Creating Capabilities, supra note 15, at 36-39 (summarizing this argument); Martha C. Nussbaum, The Costs of Tragedy: Some Moral Limits of Cost-Benefit Analysis, in Cost-Benefit Analysis: Legal, Economic, and Philosophical Perspectives 169, 
This Article, thus, ultimately straddles two important debates: one on the theoretical basis for children's rights, and another on the justifiability of making certain trade-offs between rights in a world of resource scarcity. Both areas are ones in which there is a gap in existing theory, and the place in which they intersect strikes us as a particularly useful place in which to begin to think more carefully about each question. There is, however, an obvious cost to this approach, namely that we do not provide a full treatment of either the scope, or justifiability, of all children's rights, or the question of trade-offs that are to be made between different rights claims by adults. These are questions that we must leave to a later day.

This Article is divided into three parts. Following this Introduction, Part I provides a brief summary of a CA, including a discussion of how it justifies the recognition of children's rights as a distinct species of human rights, and also does better in explaining the scope of such rights than rival social contract approaches. Part II considers potential justifications for giving special priority to children's rights, by first considering and rejecting ideas about children's innocence, and the absolute priority of equal opportunity principles, and then developing two affirmative justifications for giving special priority to children's rights based on considerations of vulnerability and cost-effectiveness. Part III considers the range of potential extensions, and limitations, on the logic of each of these two latter principles. This Article then briefly concludes.

\section{Universal Rights \& A Capabilities Approach}

The CA (also known as the "Human Development Approach"28) was introduced as an alternative to growth-based models of development that equate improvement in the quality of life in a nation with increased GDP per capita. Proponents of the CA argue that the growth-based model is deficient in at least two ways: first, it neglects distribution, and thus can give high marks to nations containing enormous inequalities. ${ }^{29}$ Second, it fails to disaggregate and separately consider distinct aspects of a human life, such as health, education, and political rights and liberties, which are not well correlated with GDP. ${ }^{30}$ The basic idea behind the approach was summed up well by

169-200 (Matthew D. Adler \& Eric A. Posner eds., 2000) [hereinafter Nussbaum, The Costs of Tragedy].

28 Nussbaum, Creating Capabilities, supra note 15, at 17. Nussbaum prefers "Capabilities Approach" because she is concerned with the capabilities of nonhuman animals as well as humans. For discussion, see generally Nussbaum, Frontiers, supra note 15, at ch. 6 .

29 Nussbaum, Creating Capabilities, supra note 15, at 48-49.

$30 \quad I d$. at 49 . These are not the only arguments against the growth-based model. As Nussbaum points out, "even if we were committed to measuring quality of life in narrowly 
economist Mahbub Ul Haq in the first of the Human Development Reports of the United Nations Development Programme in 1990:

People are the real wealth of a nation. The basic objective of development is to create an enabling environment for people to enjoy long, healthy and creative lives. This may appear to be a simple truth. But it is often forgotten in the immediate concern with the accumulation of commodities and financial wealth. ${ }^{31}$

In other words, rather than focusing simply on economic growth, development policy ought to focus on people's real opportunities.

The CA begins, then, from a very simple question: What are people really able to do and to be? "Capabilities" are the answer to that question: people's real opportunities for functioning and choice. (Sen calls capabilities "substantive freedoms."32) Proponents of a CA hold that each and every person matters: this is what Nussbaum has called the "principle of each person as end." 33 In other words, it is not enough to secure capabilities to a region, or a group, or even a family. The approach asks how each and every person is doing, and its goal is the empowerment of each. Children are no exception: all human beings possess equal and inalienable human dignity, whatever their attainments, talents, or potential, and all are equally entitled to all the capabilities on the list. ${ }^{34}$

Some proponents of a CA use the concept of capabilities only comparatively, refusing to endorse any definite set of norms. Nussbaum, however, has used the concept to develop a partial theory of social justice, beginning from the idea of human dignity. ${ }^{35}$ In her approach, every person is held to possess full and equal human dignity-unless in a permanent vegetative condition or otherwise totally

monetary terms . . . it is far from clear that GDP per capita is the most interesting notion to consider." Id. at 48 .

31 United Nations Development Programme, Human Development Report 1990, at 9.

32 See Amartya Sen, Development as Freedom 18 (1999) ("The success of a society is to be evaluated ... primarily by the substantive freedoms that members of that society enjoy." (emphasis added)).

33 See Nussbaum, Creating Capabilities, supra note 15, at 35; Nussbaum, Women and Human Development, supra note 15 , at 74 .

$34 C f$. Nussbaum, Creating Capabilities, supra note 15, at 31 ("But whereas there is room to argue about whether innate potential differs across people, human dignity, from the start, is equal in all who are agents in the first place . ...") (emphasis added).

35 It is important to stress in this context that the CA is not a theory of human nature: it does not read off norms from the list of capacities that human beings actually have. Indeed, some undoubted human capacities (for example, the capacity for cruelty) are bad and should not be developed. C $f$. id. at 28 (explaining that one would not describe as "'mutilated and deformed' . . . a child whose capacity for cruelty . . . is starved and thwarted by familial and social development . . . even if we granted that these capacities have their basis in human nature"). The CA is thus evaluative, and asks which capabilities that human beings may be able to attain are most relevant to the idea of a life worthy of human dignity. 
and irrevocably cut off from striving and sentience. ${ }^{36}$ She then argues that a life worthy of human dignity requires at least a minimum threshold level of certain central capabilities, of which she tentatively proposes a list. ${ }^{37}$ The list is emphatically a list of separate compo-

36 Id. at 29-31.

37 The Central Human Capabilities:

1. Life. Being able to live to the end of a human life of normal length; not dying prematurely, or before one's life is so reduced as to be not worth living.

2. Bodily health. Being able to have good health, including reproductive health; to be adequately nourished; to have adequate shelter.

3. Bodily integrity. Being able to move freely from place to place; to be secure against violent assault, including sexual assault and domestic violence; having opportunities for sexual satisfaction and for choice in matters of reproduction.

4. Senses, imagination, and thought. Being able to use the senses, to imagine, think, and reason-and to do these things in a "truly human" way, a way informed and cultivated by an adequate education, including, but by no means limited to, literacy and basic mathematical and scientific training. Being able to use imagination and thought in connection with experiencing and producing works and events of one's own choice, religious, literary, musical, and so forth. Being able to use one's mind in ways protected by guarantees of freedom of expression with respect to both political and artistic speech, and freedom of religious exercise. Being able to have pleasurable experiences and to avoid nonbeneficial pain.

5. Emotions. Being able to have attachments to things and people outside ourselves; to love those who love and care for us, to grieve at their absence; in general, to love, to grieve, to experience longing, gratitude, and justified anger. Not having one's emotional development blighted by fear and anxiety. (Supporting this capability means supporting forms of human association that can be shown to be crucial in their development.)

6. Practical reason. Being able to form a conception of the good and to engage in critical reflection about the planning of one's life. (This entails protection for the liberty of conscience and religious observance.)

7. Affiliation. (A) Being able to live with and toward others, to recognize and show concern for other human beings, to engage in various forms of social interaction; to be able to imagine the situation of another. (Protecting this capability means protecting institutions that constitute and nourish such forms of affiliation, and also protecting the freedom of assembly and political speech.) (B) Having the social bases of self-respect and nonhumiliation; being able to be treated as a dignified being whose worth is equal to that of others. This entails provisions of nondiscrimination on the basis of race, sex, sexual orientation, ethnicity, caste, religion, national origin.

8. Other species. Being able to live with concern for and in relation to animals, plants, and the world of nature.

9. Play. Being able to laugh, to play, to enjoy recreational activities.

10. Control over one's environment. (A) Political. Being able to participate effectively in political choices that govern one's life; having the right of political participation, protections of free speech and association. (B) Material. Being able to hold property (both land and movable goods), and having property rights on an equal basis with others; having the right to seek employment on an equal basis with others; having the freedom from unwarranted search and seizure. In work, being able to work as a human being, exercising practical reason and entering into meaningful relationships of mutual recognition with other workers.

Nussbaum, Creating Capabilities, supra note 15, at 33-34. 
nents, distinct in quality-thus, we cannot satisfy a person's entitlement to one of them by simply giving a larger amount of another one. ${ }^{38}$ And all are held to be essential for minimal social justice for each and every person. ${ }^{39}$

While one might employ the notion of capabilities in many sectors of society, formal and informal, civil and political, Nussbaum's version of the CA concentrates on the formulation of basic political principles as a template for a nation's fundamental constitutional and legislative entitlements-as well as for norms in international law. ${ }^{40}$ Nussbaum, indeed, considers the CA to be a species of a human rights approach, because, like human rights approaches, it sees all human beings as having certain fundamental entitlements that cannot be abridged or overridden without injustice. ${ }^{41}$

Thus, as noted at the outset, a CA provides a clear account not only for why children should be recognized as rights bearers, but also for why CROC and various national constitutions recognize various rights for children with sensitivity to both agency and welfare needs. ${ }^{42}$ The idea of agency has a central role to play in the CA: the CA sees people as striving agents, and in contrast to approaches that aim only at the satisfaction of preferences, it aims at supporting the growth of agency and practical reason. ${ }^{43}$ This emphasis on agency, under a CA, further means that children should be afforded the maximum scope

38 See id. at 35 ("A nation cannot satisfy the need for one capability by giving people a large amount of another, or even by giving them some money.").

39 Id. at 36.

40 See Nussbaum, Creating Capabilities, supra note 15, at 166; Nussbaum, Frontiers supra note 15, at 202; Nussbaum, Women and Human Development, supra note 15, at 70-71. For the connection of the approach to an idea of overlapping consensus and the Rawlsian concept of "political liberalism," see Nussbaum, Creating Capabilities, supra note 15, at 19, 109. See generally Martha C. Nussbaum, Perfectionist Liberalism and Political Liberalism, 39 Phil. \& PUB. Aff. 3 , 4 (2011) (arguing "that political liberalism is superior to perfectionist liberalism as a basis for political principles in a pluralistic society").

41 See Amartya Sen, Elements of a Theory of Human Rights, 32 Phil. \& Pub. Afr. 315, 332-33 (2004) (explaining that a CA distinguishes between what one values doing or being and the means one has to achieve what one values). See generally Martha C. Nussbaum, Capabilities, Entitlements, Rights: Supplementation and Critique, 12 J. Hum. Dev. \& Capabilities 23 (2011) [hereinafter Nussbaum, Capabilities, Entitlements, Rights] (exploring the "very close" relationship between capabilities and human rights).

42 See supra notes 16-17 and accompanying text.

43 See supra note 34 and accompanying text. The word "autonomy" is often used in this context. See, e.g., Michael D.A. Freeman, The Limits of Children's Rights, in The Ideologies of Children's Rights 29, 37 (Michael Freeman \& Philip Veerman eds., 1992) ("The view I put forward is premised on the need to respect individual autonomy and to treat persons as equals." (emphasis added)). We prefer, however, to use more neutral words. Autonomy is historically linked to the rejection of religious authority. It means being a law unto oneself, as contrasted with following God's law. See generally J.B. SchneEwind, The Invention of Autonomy: A History of Modern Moral Philosophy (1998) (arguing throughout that this is the right way of reading the history of the concept). The CA, as a form of political liberalism, does not ground political principles in any particular comprehensive religious or secular doctrine-or in the denial of one. See Nussbaum, Creating 
for decisional, freedom consistent with their actual—or potentialcapacity for rational and reasoned forms of choice, or judgment. ${ }^{44}$

For adolescents in particular, this may mean recognizing a range of rights to sexual and reproductive choice, religious choice, and choices regarding custody. ${ }^{45}$ In many cases, it will also mean granting at least certain decisional rights to younger children. For young children, as Emily Buss notes, the right to make certain decisions provides an important opportunity to practice thinking, and making decisions, within certain protected bounds, so as to develop their future capacity for meaningful agency. ${ }^{46}$ This also clearly accords with the terms of both Articles 5 and 12 of CROC, which provide that state parties have a duty to act "in a manner consistent with the evolving capacities of the child" and to ensure that any "child who is capable of forming his or her own views" has a "right to express those views freely in all mat-

CAPABiLities, supra note 15 , at $89-93$. On the concept of political liberalism, see supra note 40 .

44 There is, of course, a vigorous debate among children's rights scholars as to precisely how broad such decisional rights should be. Compare Richard FARSON, Birthrights 175-90 (1974) (arguing that " $[\mathrm{t}]$ he liberation of children requires that they be given the right to vote"), and John Holt, Escape From Childhood 18 (1974) (defending the view that "the rights, privileges, duties, [and] responsibilities of adult citizens be made available to any young person, of whatever age, who wants to make use of them"), with Freeman, supra note 43, at 37-39 (defending greater limits on such rights, based on the need to protect children's future capabilities), and Nolan, Children's Socio-Economic Rights, supra note 9, at 10 (arguing that "child dependence cannot be ended merely by social or political change"). For a useful summary and discussion, see $i d$. at 12-13.

45 Whether the recognition of rights—such as the right to sexual choice-is justified will depend in part on the level of knowledge and education on relevant issues in a society, as well as background norms of gender equality that may affect issues of (informed) consent. Cf. Archard, supra note 10, at 74-81. The right to vote, we noted in the Introduction, is a harder case, but again, the emphasis on agency means that the CA does not close off the possibility of giving limited voting rights in some areas to adolescents. See supra note 13 and accompanying text.

46 See Emily Buss, What the Law Should (And Should Not) Learn from Child Development Research, 38 Hofstra L. Rev. 13, 45 (2009) ("We sometimes argue for autonomy rights not so much because adolescents 'are ready' to exercise them, but because they need practice to learn how to exercise their rights well.”). Compare Katherine Hunt Federle, Looking Ahead: An Empowerment Perspective on the Rights of Children, 68 Temple L. Rev. 1585, 1586 (1995) (putting forth the idea that "[r] econceputalizing rights as power permits us to look ahead to a time when children may be respected as powerful, rights-bearing individuals"), and Katherine Hunt Federle, Rights, Not Wrongs, 17 Int'L J. Children's Rts. 321, 329 (2009) (arguing that the point of children's rights is to "create mutual zones of respect, challenging those who want to act in the best interests of children to promote the empowerment of children instead"), with Freeman, supra note 43, at 37-39 (arguing that question is "what sort of action or conduct would we wish, as children, to be shielded against on the assumption that we would want to mature to a rationally autonomous adulthood"), and Nolan, Children's Socio-Economic Rights, supra note 9, at 12 (arguing that the work of child liberationists "fails to adequately appreciate the way in which the exercise of such rights (not to mention duties) may impact on the child's enjoyment of other rights, both now and in the future"). 
ters affecting the child" and to have those views given "due weight in accordance" with his or her "age and maturity." 47

At the same time, an important contribution of the CA is that it emphasizes that rights are not fully secured unless the related capabilities are actually present: otherwise rights are mere words on paper. ${ }^{48}$ It demonstrates, in other words, that all human capabilities have social and economic conditions that require affirmative government action (and government expenditure) for their realization. In that sense, there is no such thing as a true "negative liberty" under CA: all basic liberties require government action, including, but not limited to, the inhibition of harmful action by others. ${ }^{49}$ Children's rights are, again, also no exception under a CA. ${ }^{50}$

In defining the meaning of equal rights for different groups, a CA also insists that we should start with an understanding of how groups and individuals differ in their requirements, given both physical and cognitive differences, but also differences of social starting point. ${ }^{51}$ Indeed, it is precisely on account of the importance of context in determining what people are able to do and be that the CA has been defended as superior to resource-based approaches: two people may be given the same amount of some all-purpose resource such as wealth and income, but differ in their real capabilities, whether because they have different physical needs or because they start from different social positions. ${ }^{52}$ Children, in many cases, will also clearly different from adults in the support they require from the state, in order to develop and enjoy their capabilities. ${ }^{53}$

The entitlements of children have clear points of analogy in this context to the rights of adults with cognitive disabilities, and the CA

\footnotetext{
47 CROC, supra note 7, at arts. 5, 12.
}

48 Sen denies that rights are intrinsically connected to government duties, but Nussbaum holds that they are and criticizes Sen's argument. Compare Sen, supra note 41, at 340 ("The recognition of human rights is not an insistence that everyone everywhere rises to help prevent every violation of every human right no matter where it occurs."), with Nussbaum, Capabilities, Entitlements, Rights, supra note 41, at 26 ("[T] he whole world is under a collective obligation to secure the capabilities to all world citizens, even if there is no worldwide political organization.").

49 See Nussbaum, supra note 41, at 26-27.

50 See infra notes 147-48 and accompanying text.

51 For a discussion of the similarities and differences between children and other groups in terms of enjoyment of their welfare rights, see Nolan, Children's Socio-EcoNOMIC Rights, supra note 9, at 13-21.

52 See Nussbaum, Creating Capabilities, supra note 15, at 35 ("At times group-based policies (for example, affirmative action) may be effective instruments in the creation of individual capabilities, but that is the only way they can be justified.").

$53 I d$. at 26 ("Children, of course are different; requiring certain sorts of functioning of them (as in compulsory education) is defensible as a necessary prelude to adult capability.”). 
has been extensively developed in the latter area. ${ }^{54}$ Nussbaum has argued that, as bearers of equal human dignity, adults with cognitive disabilities are entitled to all the capabilities on the list, up to the threshold level set for all. ${ }^{55}$ To say anything else would be to deny or diminish their full and equal humanity. ${ }^{56}$ Getting them above the threshold, however, may require special policies. ${ }^{57}$ While in areas such as health and bodily integrity, this may be relatively straightforward, in others, such as those involving rights to political and civil liberty, it may require complex forms of accommodation designed to allow a person to choose the function in question directly, or to exercise the right by appropriate surrogate. ${ }^{58}$

Another important analogy between children and those with severe cognitive disabilities, in this context, is that they are also largely overlooked by theories of justice in the social contract tradition. ${ }^{59}$ Such theories generally stipulate, for example, that the parties in the contract process are (in the words of John Locke) "free, equal and independent." 60 They are imagined as adults, dependent on nobody, roughly equal not only in moral standing, but also in physical and

54 See generally Nussbaum, Frontiers, supra note 15, at ch. 3 (discussing the intersection of capabilities and disabilities). Nussbaum identifies that "[t]he problem of constructed failure to fulfill human potential is even more acute in the case of people with mental impairments." Id. at 189.

55 See supra notes 21-22 and accompanying text.

56 See supra notes 21-22 and accompanying text.

57 Areas such as health and bodily integrity are relatively straightforward in this context, but puzzles arise when we consider areas such as education and especially, the political and civil liberties. For education, the approach taken by the United States under the Individuals with Disabilities Education Act (IDEA) should be favored: the maximal development of the individual child's abilities, in accordance with an Individualized Education Plan. See 20 U.S.C. $\$ 1414$ (d) (3) (A) (2006). In the areas of political and civil liberty-and in related areas such as property and contract - the best alternative is always one that permits the individual herself to choose the function in question. Thus, if assistance and explanation at the polling place will enable the person with a cognitive disability to vote, that assistance is required. See Nussbaum, The Capabilities of Persons with Cognitive Disabilities, supra note 18, at 89. Cf. Help America Vote Act, 42 U.S.C. \$ 15481 (2006) ("The voting system shall . . . be accessible for individuals with disabilities, including nonvisual accessibility for the blind and visually impaired, in a manner that provides the same opportunity for access and participation (including privacy and independence) as for other voters ....”). Where that is not possible, given the nature and extent of the person's disability, the approach recommends surrogacy: the surrogate will attempt to ascertain the views and wishes of her "client," and, where this is impossible, will vote in that person's interest. See Nussbaum, The Capabilities of People with Cognitive Disabilities, supra note 18, at 91-93. Nussbaum argues that a failure to give that person a vote, even when only a surrogate can actually exercise the function, is a failure to treat this person as a fully equal human being and citizen. Id. at 91. For discussion, see $i d$. at 75-76, 84-87, 89.

$58 \quad I d$. at 93.

59 See Nussbaum, Frontiers, supra note 15, at 103-04; see also Nussbaum, The Capabilities of People with Cognitive Disabilities, supra note 18, at 333-34 (discussing variations of social contract theory).

60 John Locke, Two Treatises of Government, Second Treatise $§ 95$, at 348-49 (Peter Laslett ed., Cambridge Univ. Press 1960) (1689). 
mental powers. ${ }^{61}$ Although there are theoretical reasons for this hypothetical simplification-because it serves to dramatize the fact that, once we imagine away artificial distinctions of class and wealth, human beings really are in many instances roughly equal in power, and thus stand to gain from cooperation-the fiction eliminates much that characterizes real life. ${ }^{62}$ Childhood and old age are entirely omitted, as are periods of disability in the "prime of life," and, of course, the lifelong disabilities with which many people live. ${ }^{63}$ Thus, while such theories prove able to deal well with issues of justice involving wealth, class, race, and gender, they have glaring weaknesses in dealing both with lifelong disability and with the human life cycle. Nussbaum has discussed this issue in the context of disability, ${ }^{64}$ but it clearly pertains to children as well: theories grounded in the classical social contract cannot adequately incorporate children's unusual vulnerability and their needs for care. Nor, in fact, can they conceive of children's fully equal humanity, since equal humanity is connected to the hypothesized equality of physical and mental powers.

This difference between theories in the social contract tradition and the CA is also especially stark when it comes to the rights of very young children. Article 1 of CROC, for example, provides that "every human being below the age of eighteen years" is protected by the Convention, unless they are an adult under national law. ${ }^{65}$ The U.N. Committee on the Rights of the Child has also affirmed in its General Comment Number 7 that "young children are holders of all the rights enshrined in the Convention" and "are entitled to special protection measures and, in accordance with their evolving capacities, the progressive exercise of their rights." 66 While social contract theories provide no account for why this makes sense, a CA provides a clear explanation for why all children-including very young children-are entitled to be treated as rights bearers.

The starting point for the CA is the fact that human beings come into the world with a variety of inchoate capacities that need development. ${ }^{67}$ The CA argues that these nascent abilities exert a moral

\footnotetext{
61 Nussbaum, Frontiers, supra note 15, at 103-04.

62 Id. at 104.

$63 I d$. at $96-103$.

64 See id. at 103-54

65 CROC, supra note 7.

66 Comm. on the Rights of the Child, Gen. Comment No. 7 on its 40th Sess., Sept. 12-30, 2005, Implementing Child Rights in Early Childhood, U.N. Doc. CRC/C/GC/7/ Rev.1 (Sept. 20, 2006), available at http://www2.ohchr.org/english/bodies/crc/docs/AdvanceVersions/GeneralComment7Rev1.pdf.

67 See Nussbaum, Constitutions and Capabilities, supra note 3, at 49 ("Human abilities come into the world in a nascent or undeveloped form and require support from the environment-including support for physical health and especially, here, for mental development-if they are to mature in a way that is worthy of human dignity.").
} 
claim that they should be developed up to the point at which they reach the threshold level of each capability specified on the capabilities list. Without that development, they are fruitless, cut off, only a shadow of what they might be. ${ }^{68}$ This idea of waste and tragedy is at the heart of the political imperatives generated by the CA. The theory is thus in its very nature intensely focused on early childhood, as a time when critical forms of support for development are either present or absent. Adam Smith, observing that children in Scotland were sent to publicly provided schooling, while children in England went straight into the factory, says that the human capacities of the English children are "mutilated and deformed" by that treatment. This is in fact the core moral intuition that guides the CA. ${ }^{69}$

At the same time, the focus on dignity under a CA also means that there are important differences between theories in the social contract tradition and a CA when it comes to various limits on the rights of children imposed by CROC and various national constitutions, in areas such as voting and jury service. ${ }^{70}$ The focus on dignity under a CA means that (by contrast to a social contract approach), the key question is always what measures are required to show full respect to the equal human dignity of each. ${ }^{71}$ Thus the question of political rights for children is at least on the table in the CA, whereas it is not in the social contract tradition. If, however, there are actual differences in the internal ${ }^{72}$ capabilities of the average child or teenager, compared to similarly situated adult, denying children access to jury service, or the vote, need not send any message of disrespect, or exclusion, to any child-whereas it almost certainly would to any adult citizen. ${ }^{73}$ It may thus also be legitimate for the state to defer access to

\footnotetext{
68 See id. at 50.
}

69 For Smith's relation to the CA and this passage in particular, see $i d$. at 46-50.

70 See generally Children And Citizenship (Antonella Invernizzi \& Jane Williams eds., 2008) (providing a useful general discussion of children's citizenship rights).

71 See supra notes $32-34$ and accompanying text.

72 For more on the difference between "internal" and "combined" capabilities, see Nussbaum, Creating Capabilities, supra note 15, at 21. Internal capabilities are "characteristics of a person (personality traits, intellectual and emotional capabilities, states of bodily fitness and health, internalized learning, skills of perception and movement)." Id. These are developed through environmental input and are not innate, but they may be present without guaranteeing a person's freedom to choose and act. See id. When all the conditions are in place for a real choice of a given function, then the person has a "combined capability." Id. A person may, for example, be well educated and capable of freedom of speech in the internal sense, but lack it in the combined sense because of repressive political institutions. Id.

73 See Steven Lecce, Should Democracy Grow Up? Children and Voting Rights, 9 INTERgenerational Just. Rev. 133, 134 (2009) (arguing that there is "nothing necessarily objectionable about using age as a reliable proxy for various competences that might be relevant to people's abilities to effectively discharge rights and responsibilities," whereas reliance on age alone would, like reliance on race or sex, be clearly morally objectionable). 
such rights, even where older children are otherwise subject to the burdens and benefits of the law. ${ }^{74}$

A deferral of this kind is likely to promote the long-term development of relevant capabilities for older children. One could imagine, for example, that deferring access to the vote could instill in young people a sense of the seriousness of voting, and the need for mature and informed judgment, as a voter, but also that it could discourage political engagement at a crucially formative time. ${ }^{75}$ A CA thus merely sanctions the possibility that it could be legitimate for a democracy to delay access to the vote for children. It does not suggest that it will be legitimate, in all cases, for it to do so. ${ }^{76}$

This understanding, however, is entirely consistent with the omission of voting rights from an international human rights instrument such as CROC, as it leaves the issue to be resolved according to the particular national and historical circumstances. ${ }^{77}$

\section{II}

\section{Special Priority for Children?}

In other respects, however, there is a potential tension between a $\mathrm{CA}$ and aspects of CROC and national constitutions protecting children's rights, in that in recognizing certain rights for children, such instruments sometimes purport to give special priority to children, at the potential direct expense of adults.

Not all forms of special priority for particular rights-claimants will raise difficulties under a CA. This is especially clear where one person's choices are likely to cause harm to another's central capabilities, since the capabilities have already been defined so as not to give people any right to violate the rights of others. ${ }^{78}$ While the outer boundaries of such a harm principle are often difficult to define, the basic idea behind such a principle is clear: one person loses any legitimate

74 For a critical exploration of the logic of this argument under social contract-based approaches, see for example, Archard, supra note 10, at 70-73.

$75 C f$. Lecce, supra note 73, at 137 (suggesting that, in the context of the right to vote, "children's present incapacities might, themselves, be partially related to their political disenfranchisement").

76 Another potential reason for children to be granted the right to vote, for example, is that it may help overcome a systematic failure by democratic policy makers, in a particular national context, to pay attention to the needs and interests of children. See generally Elizabeth F. Cohen, Neither Seen nor Heard: Children's Citizenship in Contemporary Democracies, 9 Citizenship Stud. 221 (2005) (discussing the strengths and weaknesses of this as a potential justification for giving voting rights to children); Lecce, supra note 73, at 136 (same); Nolan, The Child as "Democratic Citizen," supra note 13, at 769-74 (same). Such an instrumental justification for granting voting rights to children will also tend, in most cases, to be entirely consistent with a CA.

77 For critical discussion of this "participation gap" under CROC, however, see Nolan, The Child as "Democratic Citizen," supra note 13, at 774-80.

78 See supra note 28. 
claim to exercise their capabilities in a certain way when such action undermines the central, or fundamental, capabilities of others. ${ }^{79}$

This principle can also be applied to justify certain forms of restrictions on the freedoms of adults to make choices that affect the future capabilities of their children. In the United States, for example, adults have rights to liberty of conscience in religious matters that extend to their health choices, even when those choices involve forgoing lifesaving treatment. ${ }^{80}$ Thus, adult Jehovah's Witnesses may sometimes lawfully refuse blood transfusions. ${ }^{81}$ But adults, in many cases, cannot refuse essential medical treatment for their children on religious grounds: Christian Scientists, Jehovah's Witnesses, and other sects have all been denied the right to enforce their religious medical choices on their children. ${ }^{82}$ Another similar line of cases pertains to

79 For debate between Sen and Nussbaum in this area, see Nussbaum, Creating CapaBILITIES, supra note 15, at 71-73 (questioning whether "promoting freedom is even a coherent political project"); Nussbaum, Capabilities as Fundamental Entitlements, supra note 15, at 47 (describing as "hopelessly vague" Sen's endorsement of "freedom/capability"). In essence, Sen holds that it is always right to expand the set of capabilities that people have, no matter the content of the capabilities. See Nussbaum, Capabilities as Fundamental Entitlements, supra note 15, at 44-45. Nussbaum argues that we must not acknowledge as "central capabilities," and certainly not seek to expand, those that involve violation of the rights of others. Nussbaum uses as examples the capability to harass women in the workplace, the capability to refuse employment on grounds of race, and the capability to pollute the environment. Id. Sen's reply is that capability is always good in itself, though it might be misused. He gives the example of male strength: it is a good thing in itself, though it might be used to beat up women. Id. at 46 (citing Sen's remarks in Bielefeld in July 2001). Nussbaum argues that this is simply not satisfactory: some capabilities contain harm in their very definition (for example, those that she has mentioned as instances). Id. at 46-47. There simply is nothing good about the capability to refuse employment to African-Americans, she argues, so the law should remove it. See id.

80 See Cruzan v. Dir., Mo. Dep't of Health, 497 U.S. 261, 270 (1990) (recognizing that "cases involv[ing] patients who refuse[] medical treatment forbidden by their religious beliefs" implicate "First Amendment rights as well as common-law rights of selfdetermination").

81 See, e.g., Holmes v. Silver Cross Hosp., 340 F. Supp. 125, 130 (N.D. Ill. 1972) ("[A] state-appointed conservator's ordering of medical treatment for a [Jehovah's Witness] in violation of his religious beliefs, no matter how well intentioned the conservator may be, violates the First Amendment's freedom of exercise clause in the absence of some substantial state interest.").

82 See, e.g., Walker v. Superior Court, 763 P.2d 852, 855 (Cal. 1988) (holding that a Christian Scientist mother could be prosecuted for involuntary manslaughter and felony child endangerment after her child died of meningitis "after receiving treatment by prayer in lieu of medical attention"); People ex rel. Wallace v. Labrenz, 104 N.E.2d 769, 773 (Ill. 1952) (also permitting a blood transfusion for a child over the objections of Jehovah's Witness parents on the grounds that "a child whose parents refuse to permit a blood transfusion, when lack of a transfusion means that the child will almost certainly die or at best will be mentally impaired for life, is a neglected child"); Lundman v. McKown, 530 N.W.2d 807, 828-29 (Minn. Ct. App. 1995) (holding Christian Scientist caregivers liable in a wrongful death action for failing to treat symptoms of juvenile-onset diabetes); State v. Perricone, 181 A.2d 751, 757 (N.J. 1962) (holding that the religious beliefs of parents who were Jehovah's Witnesses did not permit them to refuse blood transfusions for a dying child, or, in the words of the court, to make "martyrs" of their children (quoting Prince v. 
education: parents may not refuse compulsory education for their children, although the Old Order Amish were given an accommodation that permitted them to withdraw their children from school at age fourteen. ${ }^{83}$ The opinions in these cases, however, explicitly discussed the futures of the children and whether they were likely to have employment opportunities. ${ }^{84}$

Absent such a direct conflict between the rights of parents and children, however, the commitment to the universal protection of rights under a CA means that it will be far more difficult to justify the allocation of special priority to children. The CA provides an account of each person's fundamental entitlements-entitlements that must be secured to everyone as a necessary condition of minimal social justice. ${ }^{85}$ All entitlements are held to be required by the notion of a life worthy of people's equal human dignity. ${ }^{86}$ When, therefore, a given capability cannot be secured to everyone, or when securing one capability means forgoing another, that is a tragic conflict, which deserves to be marked as such. ${ }^{87}$ Both CROC and various national constitutions, however, frequently give just this kind of special priority to chil-

Massachusetts, 321 U.S. 158, 170 (1944))); see also Isolde Raftery, Changes in Oregon Law Put Faith-Healing Parents on Trial, N.Y. TIMEs, May 30, 2011, at A14 (describing a recent episode concerning the Followers of Christ Church: parents who refused medical treatment on religious grounds for a child with a benign tumor that might cause blindness if untreated were indicted for first-degree criminal mistreatment in Oregon. The child was placed in foster care for two months while she received treatment.). For discussion of the constitutional standard, see Martha C. Nussbaum, Liberty of Conscience: In Defense of America's Tradition of Religious Equality 115-74 (2008).

83 See Wisconsin v. Yoder, 406 U.S. 205, 234 (1972). Homeschooling is another potentially important exception granted to parents in the United States, in this context. Cf. Combs v. Homer-Center Sch. Dist., 540 F.3d 231, 247 (3d Cir. 2008) (recognizing a parent's right to direct a child's education, but holding that "the right to be free from all reporting requirements and 'discretionary' state oversight of a child's home-school education [,] has never been recognized" (emphasis added)). Whether home schooling as currently practiced, with virtually no oversight or curricular requirement, is compatible with the development of children's capabilities as citizens is, however, open to question. In Mozert v. Hawkins County Board of Education, 827 F.2d 1058, 1060, 1068 (6th Cir. 1987), the court reasoned that the government has a compelling interest in ensuring that children learn about the varied religious and ethnic groups that compose their society-in response to a "born again Christian" mother who wanted her children to be shielded from such knowledge, asserting that the Bible was all her children needed to know. See id. But if the parent had simply chosen homeschooling, the entire issue would not have arisen-and the children would not have learned about other types of people.

84 See Yoder, 406 U.S. at 228-29, 239-40, 245-46. The case has been criticized in many ways; one clear problem is that the future employment opportunities of girls were not discussed. After withdrawal from school, Amish boys learn carpentry and farming, highly exportable skills; girls learn only household management. See Nussbaum, Women and Human Development, supra note 15, at 233.

85 See Nussbaum, Creating Capabilities, supra note 15, at 71.

86 See Nussbaum, Women and Human Development, supra note 15, at 5.

87 See Nussbaum, Creating Capabilities, supra note 15, at 36-39. 
dren's rights, without explicitly acknowledging the moral difficulty, in some cases amounting to a tragic choice, that this involves.

Take the provisions in various rights instruments giving special priority to "the best interests of the child" in various areas of state action concerning children. ${ }^{88}$ Article 3(1) of CROC provides that in the context of state action (as opposed to inaction) "concerning children ... the best interests of the child shall be a primary consideration." 89 Constitutions such as the Brazilian constitution go even further, providing that it is the duty of the state to ensure "children and adolescents, with absolute priority, the rights to life, health, nourishment, education, leisure, professional training, culture, dignity, respect, liberty and family and community harmony." 90 While such provisions do not always limit fundamental rights for adults (not every claim to individual liberty counts as fundamental under a CA, according to Nussbaum), ${ }^{91}$ they clearly have the potential to do so in some cases, such as those involving decisions about family (re)location or freedom of movement. 92

A similar form of special priority is also given quite expressly to children by CROC and various national constitutions in the context of various so-called "socioeconomic" or "welfare" rights. ${ }^{93}$ When it comes to the right to health, for example, CROC requires states parties to take "all appropriate legislative, administrative, and other measures . . . to the maximum extent of their available resources," for the implementation of the right to "the highest attainable standard of

88 See, e.g., CROC, supra note 7, at art. 3, § 1; see also Philip Alston, The Best Interests Principle: Towards a Reconciliation of Culture and Human Rights, 8 INT'L J.L. \& FAM. 1, 3-4 (1994) (collecting other human rights instruments invoking the same or similar phrase).

89 This provision was also clearly intended to make the best interests of the child paramount over the interest of adults, except in a limited range of circumstances. See Philip Alston, The Legal Framework of the Convention on the Rights of the Child, 91/2 BuLL. Hum. RTs. 1, 9 (1992). See generally Alston, supra note 88 (exploring the significance of the "best interests" principle in the "overall human rights context").

90 Constituição Federal [C.F.] [Constitution] art. 227 (Braz.). (emphasis added); see also Nolan, Children's Socio-Economic Rights, supra note 9, at 239 n.60.

91 See Nussbaum, Creating Capabilities, supra note 15, at 73 ("[Some freedoms] are not implicit in our conception of social justice, and certainly they should not appear in a list of fundamental constitutional rights.").

92 See, e.g., $U v U$ (2002) 211 CLR 238, 242 (Austl.) (restricting the rights of the adult female appellant to move internationally, according to a best-interests-of-the-child standard). For discussion, see Juliet Behrens, U v U: The High Court on Relocation, 27 Melb. U. L. REv. 572, 573 (2003) (encouraging legislative reform to embody presumptions which defer to the judgment of a child's primary caregiver in relocation cases).

93 From the perspective of CA, the distinction is, of course, ultimately quite artificial, given that all rights require government expenditure for their realization and preservation. See Nussbaum, Creating Capabilities, supra note 15, at 64-67. For another criticism of the distinction as artificial, see, for example, Terence Daintith, The Constitutional Protection of Economic Rights, 2 InT'L J. Const. L. 56, 57-64 (2004); Cécile Fabre, Constitutionalising Social Rights, 6 J. Pol. Phil. 263, 264 (1998); Nolan, The Child's Right to Health, supra note 9, at 145 . 
health," whereas the equivalent provisions in the ICESCR require states to take such measures only "with a view to achieving progressively the full realization of the right [ ]." ${ }^{44}$ Similarly, when it comes to the right to an "adequate standard of living" recognized by both CROC and the ICESCR, CROC requires that states parties must, "within their means... provide material assistance and support programmes" to facilitate the realization of this right, "particularly with regard to nutrition, clothing and housing," whereas ICESCR simply imposes a far more general obligation on states to "take appropriate steps to ensure the realization of this right." 95

At a national constitutional level, Section 28 of the South African constitution likewise requires that, when it comes to children, the South African government is to consider "[a] child's best interests [which] are of paramount importance" in protecting the right of every child to "basic nutrition, shelter, basic health care services and social services," whereas, for persons more generally, it is only required by Sections 26 and 27 to "take reasonable legislative and other measures, within its available resources, to achieve the progressive realisation" of equivalent rights, such as the right have access to adequate housing, health care services, sufficient food, and water. ${ }^{96}$ Similarly, in Colombia, Article 44 of the constitution provides that children have a basic right to "health and social security," 97 while citizens more generally are entitled only to "access to services that promote, protect, and rehabilitate public health," 98 and social security, the content of which may be determined by law. ${ }^{99}$

94 See CROC, supra note 7 , at arts. 4, 24, $\$ 1$; ICESCR, supra note 6 , at art. 2 . It is possible, of course, that this textual difference will be "read down" by the Committee on the Rights of the Child. See, e.g., Committee on the Rights of the Child, General Comment 5: General Measures of Implementation for the Convention on the Rights of the Child, If 5 (2003), available at http://www.unhchr.ch/tbs/doc.nsf/\%28symbol\% 29/CRC.GC.2003.5. En (suggesting that the approach of the UN Committee on Economic, Social and Cultural Rights to art. 2(1) of ICESCR should be seen as "complementary" to the approach taken to art. 4). The Constitutional Court of South Africa has taken a similar approach in Grootboom in the context of the right to shelter. See infra note 102. The text itself, however, does not make such an approach inevitable.

95 See ICESCR, supra note 6, at art. 11; CROC, supra note 7, at art. 27.

96 See S. Afr. Const., 1996, \$§ 26-28.

97 Constitución Política de Colombia [C.P.] art. 44.

98 Id. at art. 49.

99 Id. at art. 48 (recognizing social security as a "mandatory public service ... [to] be delivered under the administration, coordination, and control of the state, subject to the principles of efficiency, universality, and solidarity within the limits established by law"; an "irrevocable right" but also one that must be "gradually extend[ed]" by the state to "include the provision of services in the form determined by law"). Children under age one also have additional rights to free health care, though such rights may be regulated by law. See id. at art. 50.

A similar contrast could arguably be made under the Honduran Constitution. Compare Constitución Política de la República de Honduras art. 123, translated in Constitution of Honduras, Honduras.com, http://www.honduras.com/honduras-constitution- 
Courts in these countries have also frequently read these provisions so as to give special priority to children, as opposed to adults, as rights claimants. ${ }^{100}$ The most notable instance of this in South Africa occurred in Grootboom v. Oostenberg Municipality, ${ }^{101}$ where, at first instance, Judge Dennis Davis relied on the constitution's Section 28 to order that various local authorities provide basic shelter (that is, tents, portable toilets, and potable drinking water) to approximately 510 children and their parents, where in respect of the adult claimants themselves, he limited his order to a more general form of declaratory relief.102 Another example, though less stark, is the finding of the South African Constitutional Court (SACC) in the TAC case ${ }^{103}$ that it was unreasonable under Section 27(2) of the South African Constitution for the government to fail to provide HIV-positive women with access to anti-retroviral treatment aimed at preventing the mother-tochild transmission (MTCT) of HIV. ${ }^{104}$ (In reaching this conclusion, the SACC in no way went beyond the narrow confines of the case, by suggesting, for example, that women had an equivalent right of access to anti-retroviral treatment, post-pregnancy. ${ }^{105}$ )

In Colombia, a similar pattern can also be observed in the decision of the Constitutional Court in the landmark case of SU-225/ $98,{ }^{106}$ recognizing a right on the part of poor children to state-funded vaccination against meningitis, without any accompanying suggestion

english.html\#.TyayUCOpWtl (last visited Jan. 30, 2012) (recognizing the right of children to "grow and develop in good health"), with id. at art. 145 (recognizing a "right to health protection").

100 For discussion of this point, see Nolan, The Child's Right to Health, supra note 9, at

145.

1012000 (3) BCLR 277 (CC) (S. Afr.).

102 Judge Davis's reasoning in this context was ultimately overturned by the Constitutional Court of South Africa on appeal, but the order itself was not contested by the local municipalities, and was thus not overturned. See Gov't of the Republic of South Africa v. Grootboom 2001 (1) SA 46 (CC) at paras. 74-79 (S. Afr.) (determining that the High Court erred in holding that there is "a separate and independent right[ ] for children and their parents" to shelter and social services); Grootboom 2011 (7) BCLR 651 (CC) at paras. 5, 73-79. For discussion, see Rosalind Dixon, Creating Dialogue About Socioeconomic Rights: Strong-Form Versus Weak-Form Judicial Review Revisited, 5 InT'L J. Const. L. 391, 395-98 (2007).

103 Minister of Health v. Treatment Action Campaign (No. 2) 2002 (5) SA 721 (CC) (S.

Afr.).

104 See id. at paras. 4-5, 135; see also id. at paras. 4, 74-79 (emphasizing the importance of the rights of newborn children under Section 28 , and the way in which the case involved "the right of children to be afforded special protection").

105 There were, of course obvious strategic reasons why the plaintiffs did not raise this broader claim directly. Cf. id. at para. 19 (providing a summary of the applicants' case). However, in discussing $§ 27(2)$ the court clearly had an opportunity to make at least some tentative comments on this issue.

106 Corte Constitucional [C.C.] [Constitutional Court], mayo 20, 1998, M.P: E. Cifuentes Muñoz, Sentencia SU-225/98 (Colom.). For discussion, see Nolan, Children's Socio-Economic Rights, supra note 9, at 11; Alicia Ely Yamin \& Oscar Parra Vera, The Role of Courts in Defining Health Policy: The Case of the Colombian Constitutional Court 4 (2008) (Harvard Law School Human Rights Program), available at http:// 
that unvaccinated adults would be entitled to any equivalent form of state-funded medical treatment for the same (or similar) condition.

Existing attempts to justify this form of special priority for children's rights also tend to sit uneasily with a CA. One idea, advanced by some in the U.S., for example, is that children enjoy special rights, not shared by adults, because of the need to ensure that they have the opportunities necessary to "achieve [their] full potential as . . . selfsupporting citizen[s]." 107 Another idea, famously endorsed by Justice Powell in Plyler $v$ Doe, is that children will sometimes be deserving of special rights, not shared by adults, because they are entirely "innocent" in respect of the circumstances that have created the need for state support, or intervention. ${ }^{108}$ Neither of these arguments, however, is ultimately sufficient to justify the grant of special rights to children under a CA, when similar rights are denied to adults.

Notions of equal opportunity certainly have an important role to play in a CA. The very idea of capability is an idea of substantive opportunity, and the CA imagines human beings as striving individuals who need a supportive context in order to become capable of a range of choices of functioning. ${ }^{109}$ However, the idea of "self-supporting" adults is often used unclearly, with an implication that the main aim of the state is to avoid being burdened by costs. Thus, in Wisconsin $v$. Yoder the Supreme Court justified the withdrawal of Amish children from school by pointing to the fact that they were a prosperous community and their children would not be a drag on the public coffers. ${ }^{110}$ That is not the idea of "self-supporting" people that is used by the CA: the CA focuses on what circumstances do to create substantive opportunities for individual people; ${ }^{111}$ thus, the question that ought to be asked is how the withdrawal from school affects a wide range of opportunities for individual Amish children.

In addition, the CA also insists that the state has obligations to individuals beyond ensuring them equal access to certain basic social and economic opportunities. ${ }^{112}$ Part of the key idea behind a CA, as

www.law.harvard.edu/programs/hrp/documents/Yamin_Parra_working_paper.pdf (last visited Oct. 12, 2011).

107 See Martha Minow, Children's Rights: Where We've Been, and Where We're Going, 68 TEMPLE L. Rev. 1573, 1576 (1995) (quoting Phyllis Schafley's "Declaration of a Child's Rights").

108 See Plyler v. Doe, 457 U.S. 202, 238-39 (1982) (Powell, J., concurring) (upholding a right of access to public school education for children of undocumented aliens).

109 See Nussbaum, Creating Capabilities, supra note 15, at 21 (stating that "[o]ne job of a society that wants to promote the most important human capabilities is to support [their] development" by providing resources and education, and by supporting families).

110 See Wisconsin v. Yoder, 406 U.S. 205, 224-25, 240 (1972).

111 See Nussbaum, Creating Capabilities, supra note 15, at 18 (describing the CA as focusing on both an individual's well-being and "the opportunities available to each person").

112 See supra notes 35-39 and accompanying text. 
Part I notes, is that even an enormous amount of striving and preplanning do not necessarily protect individuals from blows that make it impossible for them to live a life worthy of full human dignity, without help from others. ${ }^{113}$ Thus the very idea that the goal of education and state support is to produce people who are "self-supporting" ignores the very great degree of vulnerability to accident that individuals retain throughout their lives, even with the best education and care.

As for ideas about children and innocence, they are ultimately insufficient to justify the simultaneous recognition of certain rights for children and denial of equivalent rights for most adults under a CA. ${ }^{114}$ The term "innocence" is used in two ways. At times it is used loosely, as a mere synonym of "vulnerability" —and in this case we have no objection to recognizing "innocence" so used (albeit confusingly) as a source of special attention. ${ }^{115}$ A CA starts with notions of human frailty and vulnerability, and it argues that, from a moral standpoint, the state has an obligation to ensure that all persons have access to a life worthy of human dignity-in their frailty and vulnerability. But at other times, the word "innocence" is used in its more accurate meaning, as the antonym of "guilt," and the idea is suggested that people lose their claim to entitlements if they are not morally good or pure in some respect: as, for example, when children are called the "innocent victims" of HIV/AIDS, with the implication that others, for example gay men, are the "guilty" victims, ${ }^{116}$ or when it is said that a nice person does not "deserve" to be killed, with the implication that homicide is less grave if the victim is, say, a prostitute or a convict. ${ }^{117}$ We utterly reject this way of thinking. All individuals are entitled to claim the protections of a CA, even those, who as (then) President Chaskalson of the South African Constitutional Court put it, are "the worst and

113 See Nussbaum, Frontiers, supra note 15, at 156-58 (discussing the mutual advantages deriving from cooperation and a shared life among the people in a society).

114 For a critical examination of these ideas in the context of children's rights, see, for example, Archard, supra note 10, at 36-41.

115 See id. at 39.

116 See, e.g., E. Glenn Schellenberg et al., "Innocent Victims" of AIDS: Identifying the Subtext, 25 J. Applied Soc. Psychol. 1790, 1791 (1995) (describing the tendency to refer to "infants, hemophiliacs, and people who had blood transfusions as 'innocent' victims of AIDS").

117 See Matthew Walberg \& Ted Gregory, Hanover Park Woman Who Feared Husband Is Found Dead, Chi. Trib., Aug. 27, 2011. At the end of a story about a woman who was first battered and then stalked and murdered by her husband, an acquaintance of the woman says: "[she] was just the nicest person. Everybody who came in [to the restaurant] loved her. She was just a great mom, a great bartender, a great co-worker. She didn't do anything wrong; she didn't deserve this." But suppose she had been a nasty person and an incompetent bartender. . . . 
the weakest amongst us."118 Notions of guilt and innocence will, accordingly, have only a quite narrow role to play under a CA.

Individuals who engage in wrongdoing may certainly be punished consistent with a CA: indeed, the concern for the dignity of victims, and their right to bodily security and control over their environment, under a CA, will often mean that a CA will require that a person be punished for their wrongful actions. ${ }^{119}$ A CA, however, also insists that any such punishment be proportionate to the relevant crime; and also that any individual wrongdoer be treated as a bearer of rights, entitled to full human dignity, in all other respects. ${ }^{120}$ This, in most instances, will also make it extremely difficult for the state to justify denying adults access to the kind of rights afforded to children. It certainly would not explain, for example, the result in cases such as Plyler, Grootboom, or TAC, even if one assumes some relevant form of wrongdoing by adults. ${ }^{121}$

While children may well be entitled to special priority when it comes to various rights, under a CA, therefore, in most cases a different justification for such priority will be required. The remainder of this Part explores two principles-one based on notions of childhood vulnerability and another on the cost-effectiveness of protecting children's rights—-that may provide such a justification.

\section{A. A Vulnerability Principle}

When people talk about children and children's rights, they often talk about the vulnerability of children. ${ }^{122}$ Unlike most nonhuman animals, children remain profoundly dependent on adults for a substantial time. Their cognitive development proceeds rapidly, so

118 S v. Makwanyane and Another 1995 (3) SA 391 (CC) at 431 para. 88 (S. Afr.). "Weakest" evidently refers to vulnerability, while "worst" underlines our point that moral guilt does not mean that a person loses fundamental entitlements. On vulnerability, see infra Part II.A.

119 See, e.g., Nussbaum, Creating Capabilities, supra note 15, at 148 ("[D]omestic violence and child sexual abuse should be aggressively policed by the state.").

120 This necessarily flows from the CA's recognition that "human dignity . . . is equal in all who are agents in the first place." Id. at 31.

121 Plyler v. Doe, 457 U.S. 202 (1982); Minister of Health v. Treatment Action Campaign (No. 2) 2002 (5) SA 721 (CC) (S. Afr.); Gov't of the Republic of S. Afr. v. Grootboom 2001 (1) SA 46 (CC) (S. Afr.). In TAC, though some adults contract HIV-AIDS as a result of consensual forms of sex or intravenous drug-use and almost all young children living with HIV have absolutely no control over the circumstances in which they contract the disease, this difference cannot mean that it is justifiable, from the perspective of a CA, to recognize a right to access to antiretroviral treatments for children, while simultaneously denying such a right for most adults. Even when the conduct through which an adult contracts HIV is illegal (intravenous drug use, for example), punishing that illegality via a later refusal of lifesaving treatment would be grossly disproportionate to the relevant form of wrongdoing involved. For discussion of the potential "wrongdoing" of adults in Grootboom, and its lack of moral opprobrium, see infra notes 180-82 and accompanying text.

122 See Minow, supra note 10, at 297. 
that within the first year they are able to see the world from the perspective of another and to make simple judgments of fairness, but they still require many years to achieve full emotional and cognitive maturity. ${ }^{123}$ Physically, they also remain unable to move from place to place on their own and are thus unable to ensure their own survival. Physical maturity takes more than a decade, ${ }^{124}$ and emotional maturity, including mature choice-making ability, arrives only in late adolescence. ${ }^{125}$ These features of the human life cycle are unique, and they mean that children are completely dependent on the care of others. Furthermore, their immobility means that, even though their cognition can develop rapidly, they remain at the mercy of their surroundings for cognitive and emotional stimulation and stability.

This form of cognitive, emotional, and physical vulnerability, we suggest, is also an important reason why CROC and various national constitutions often recognize rights in a way that is distinctive to children. Consider, for example, the provisions in CROC requiring states to encourage the production and dissemination of children's books and to protect children's right to "rest and leisure."126 Further consider the duty imposed on states by Article 37 of CROC to ensure that the detention of children is "a measure of last resort and for the shortest appropriate period of time." 127 Differences in the physical and cognitive abilities, or emotional maturity, of children may mean that these rights are simply an attempt to give substantively equal content to the same rights-to recreation, and freedom from cruel, inhuman and degrading treatment-enjoyed by adults: children's imagination and creativity, for example, are likely to be stimulated by quite different books than those that appeal to adults; and children are also likely to experience quite different levels of trauma, and psychological harm, as a result of experiences such as detention. Thus, it clearly makes sense under a CA to define children's rights in a way that is somewhat different from adults.

In focusing on children's vulnerability under a CA, however, it is also important to recognize that many forms of vulnerability experienced by children are common to others-including adults with cog-

123 See Paul Bloom, Descartes' Baby: How the Science of Human Development Explains What Makes Us Human 119-21 (2004).

124 See, e.g., Archard, supra note 10, at 27. ("[T] he 12-year-old is . . . at or close to puberty.").

125 Cf. Graham v. Florida, 130 S. Ct. 2011, 2032 (2010) ("Difficulty in weighing longterm consequences; a corresponding impulsiveness; and reluctance to trust defense counsel seen as part of the adult world a rebellious youth rejects, all can lead to poor decisions by one charged with a juvenile offense.").

126 CROC, supra note 7, at arts. 17, 31.

127 Id. at art. 37. 
nitive disabilities. ${ }^{128}$ For them as well, active state protection is needed for a wide range of capabilities, to a degree that is not required by adults without such disabilities. This difference (between children and adults with severe cognitive disabilities and other adults) is a matter of degree: all people need state protection for health, bodily integrity, the exercise of choice and agency, the opportunity for play and leisure time, the exercise of property rights, and so forth. ${ }^{129}$ In the case of children and adults with severe cognitive disabilities, however, the state must remain more deeply involved in protecting capabilities, frequently through delegation of some powers to a guardian or surrogate, but also through the supervision and limitation of those powers. ${ }^{130}$ In many respects, then, the case of children is not unique.

By itself, children's physical vulnerability, therefore, will also be insufficient in most cases to justify any special priority-as opposed to special scope-for the rights of children, as compared to adults, under a CA. Instead, what is needed is an account that focuses on the more or less unique vulnerability of children to the decisions of others-that is, those adults legally and economically responsible for their care. ${ }^{131}$

Children are economically dependent on adults, in most countries, in a variety of ways. ${ }^{132}$ They often lack the skills and training necessary to earn decent wages from any paid work they perform. They are also often prohibited from engaging in significant amounts of such work by laws requiring compulsory school attendance and prohibiting employers from hiring those below a certain age. ${ }^{133}$ The law in most countries also makes children legally dependent on parents and guardians in a variety of other ways-for example, by giving parents (and guardians) broad rights to decide questions such as where a child will live, or go to school, or how they should be represented legally and politically. ${ }^{134}$

128 See Nussbaum, Frontiers, supra note 15, at 96-98 (giving examples of adults whose mental disabilities may leave them permanently dependent upon others).

129 See id. at 168-69.

130 See id. at 195.

131 See Nussbaum, Creating Capabilities, supra note 15, at 148 (noting that state action is often needed in the policing of child abuse, child marriage, child labor, and educational decisions).

132 For discussion of children's economic powerlessness, see Nolan, Children's Socio-Economic Rights, supra note 9 , at 83-84.

133 See, e.g., Fair Labor Standards Act, 29 U.S.C. $§ 212$ (2006) (establishing federal provisions to limit child labor); Wisconsin v. Yoder, 406 U.S. 205, 215 (1972) (recognizing that while there may be a "State[ ] interest in universal compulsory education, it is by no means absolute to the exclusion or subordination of all other interests").

134 Cf. Nussbaum, Women and Human Development, supra note 15, at 230-31 (noting that states often acknowledge broad parental rights due to parents' "legitimate rights over 
There are also, in many cases, good reasons for this kind of legally sanctioned dependence. Because children do not achieve full emotional and choice-related maturity prior to adolescence, it makes sense to give parents broad decisional rights at an earlier time. Doing so simply reflects the importance of adult choice-capacities, which children are expected to develop later in time. Laws making education compulsory and banning child labor also help ensure that children in fact have the space and support necessary to develop in this way. And because, as the Introduction notes, children will ultimately attain full adult freedom, it does not denigrate them to impose such limits on their freedom in the interim.

In this respect, the position is utterly different from that of adult women, who have often been denied mature choice capabilities in many areas as a result of an artificially constructed type of infantalization. ${ }^{135}$ Even where, because of artificial restrictions on movement and education, adult women's choice-capabilities have in fact not been developed, they remain fully mature adults, and their dignity would be compromised were their rights to be made proportional to their actual educational attainment. Young children, by contrast, are not insulted by being treated as immature, and on the way to full adult choice.

By defining the usual case as one in which parents are entrusted with primary responsibility for protecting and developing the capabilities of their children, however, the CA does not say that children have to live with parental choices that in fact compromise their development, in health, education, and other areas. ${ }^{136}$ On the contrary, there is a strong argument under a CA that by sanctioning this form of legal dependence for children, the state should assume responsibility for protecting children from the consequences of the special vulnerability it creates in relation to the decisions of others-by insuring them against the risk that their parents (or legal guardian) will turn out to be unable, or unwilling, to take reasonable steps to protect their capabilities. ${ }^{137}$ This, we suggest, is ultimately the best way to understand

[their children]" and because it can be difficult to determine a child's actual choice given "parental power and the child's economic dependency").

135 See, e.g., Planned Parenthood of Se. Pa. v. Casey, 505 U.S. 833, 897-98 (1992) (criticizing the now moribund traditional common-law principle that "a woman had no legal existence separate from her husband, who was regarded as her head and representative in the social state" (citing Bradwell v. State, 83 U.S. (16 Wall.) 130, 141 (1873) (Bradley, J., concurring))).

136 See infra notes 179, 180, and 182 and accompanying text.

137 Cf. Nolan, Children's Socio-Economic Rights, supra note 9, at 8 (criticizing the "public neglect of children as an aggregated group, justified by the theory that they are solely the responsibility of their parents"). For ideas about the insurance-based function of constitutional rights in a quite different context, compare, for example, Tom GinsburG, Judicial Review in New Democracies: Constitutional Courts in Asian Cases 26 (2003) 
arguments about the special "innocence" of children in respect of the enjoyment of certain welfare rights: a total lack of control over certain decisions will give individuals a stronger claim to protection by the state than have had partial agency over relevant outcomes.

In most countries, a similar argument is widely accepted in the context of the rights of prisoners. ${ }^{138}$ Similar principles also generally apply, in tort law, where an individual exposes another person to a special-or unusual-form of risk. ${ }^{139}$ Given the commitment to equality under a CA, the position should also be no different where children are concerned.

This kind of "insurance-based" understanding of children's rights also finds strong support, we suggest, in existing IHR and constitutional contexts. Article 3(2) of CROC, for example, explicitly provides that the duty of "states parties" is to "undertake to ensure the child such protection and care as is necessary for his or her well-being, taking into account the rights and duties of his or her parents, legal guardians, or other individuals legally responsible for him or her."140 Similarly, Article 18 of CROC enshrines the principles that parents and legal guardians "have the primary responsibility for the upbringing and development of the child," and that the state's role in this context is to "render appropriate assistance to parents and legal

(noting the capacity of constitutional rights and judicial review to provide insurance to outgoing political elites), with Tom Ginsburg \& Rosalind Dixon, The South African Constitutional Court \& An Insurance-Based Theory of Socio-Economic Rights (2011) (unpublished working paper) (on file with authors) (noting the capacity of socioeconomic rights to provide political insurance to left-wing parties against the danger that certain concessions to right-wing parties, in the form of a right to property or contract, could prove unduly costly downstream).

138 For an American example, see Estelle v. Gamble, 429 U.S. 97, 104 (1976), in which the Court held that "it is but just that the public be required to care for the prisoner, who cannot by reason of the deprivation of his liberty, care for himself." (quoting Spicer v. Williamson, 132 S.E. 291, 293 (N.C. 1926)). In some cases, however, the United States Supreme Court has refused to apply this principle to children in their parents' care. See, e.g., DeShaney v. Winnebago, 489 U.S. 189, 201-02 (1989). On the analogy between the position of prisoners and children in this context, see further: Nolan, Children's SocioEcONOMic Rights, supra note 9, at 19.

139 For an Australian example, see Hill v Van Erp (1997) 188 CLR 159, 159 (Austl.) (holding a solicitor liable to a third party who did not inherit due to solicitor's negligence in preparing a will, as solicitor owed third party a duty of care based on the nature of the undertaking). For an English example, see Caparo Industries plc v. Dickman, [1990] 2 A.C. (H.L.) 605 (appeal taken from Eng.) (holding that an auditor owed a duty to shareholders and not just to client company, and finding that auditor was negligent in understating a company's financial losses). American examples can be found in the dramatic Tarasoff $v$. Regents of the University of California, 551 P.2d 334, 340 (Cal. 1976) (holding that a therapist owes a duty to the intended victim of a homicidal patient) and Rowland v. Christian, 443 P.2d 561, 568 (Cal. 1968) (ruling that a property owner owes a duty to warn those on his property about a concealed danger).

140 CROC, supra note 7, at art. 3(2). 
guardians in the performance of their child-rearing responsibilities."141

A similar form of insurance-based rationale can help explain the result in cases such as TAC and SU-225/98. While the primary obligation to provide health care services to children, as the South African Court noted in TAC, "rests on those parents who can afford to pay for such services," the state also has an obligation to provide access to health care for children being cared for by their parents and families. ${ }^{142}$ This is also especially true, the Court suggested, in circumstances such as $T A C$, where parents are "for the most part indigent and [thus] unable to gain access to private medical treatment which is beyond their means." 143 A key reason for this, as the Colombian court noted in SU-225/98, is also that, for children, poverty is almost always-and not simply often-beyond their control. ${ }^{144}$

\section{B. A Cost-Effectiveness Principle}

For many rights granted to children by IHR and national constitutions, considerations of cost will provide another potential justification for the grant of special priority to such rights, consistent with a CA.

As noted above, social cost cannot be a trump, eclipsing the equal entitlements of all persons under a CA: that is, the goal remains the full empowerment of all individuals, and the focus is always, ultimately, on the individual rather than the total or average social achievement. ${ }^{145}$ In this respect the CA differs from utilitarianism, as well as from conceptions of development that equate development with increased GDP per capita. ${ }^{146}$ From the perspective of a CA, it will thus also generally be illegitimate for a state to assign special priority to the rights of some individuals, over others, based on considerations of marginal benefit. For children, the fact that they will generally live longer than adults, and thus gain greater benefits from certain rights, is thus insufficient to justify a claim on their part to any form of special rights priority.

\footnotetext{
141 Id. at art. 18(1), 18(2).

142 Minister of Health v. Treatment Action Campaign (No. 2) 2002 (5) SA 721 (CC) at 749 para. 77 (S. Afr.).

143 Id. at 750 para. 79.

144 Corte Constitucional [C.C.] [Constitutional Court], mayo 20, 1998, M.P: E. Cifuentes Muñoz, Sentencia SU-225/98 (Colom.), para. 31. ("La pobreza de los padres y la falta de cobertura de los servicios públicos de salud, son para el niño variables que se encuentran fuera de su control. Se descubre fácilmente que, en estas condiciones, el niño a la vez que ignora su precariedad, objetivamente es un sujeto impotente ante un riesgo de una magnitud incalculable.").

145 See supra note 93 and accompanying text.

146 See Nussbaum, Creating Capabilities, supra note 15, at 47-56, 69-100.
} 
This does not mean, however, that in a world of true resource scarcity, considerations of cost will necessarily be irrelevant under a CA. In some cases, the marginal cost of satisfying a rights claim will be so low, relative to the large benefits involved to the individual, that any denial of such a claim will in fact constitute a per se affront to a person's dignity. A person denied access to a right in such circumstances might well ask: "Why am I denied access to this right, given the minimal cost to others? Surely it is because others simply do not respect me-or my life-as having full human value." From the perspective of a CA, such an answer is also deeply troubling: it suggests a clear departure from Kantian ideas about human dignity, and universal respect for personhood. ${ }^{147}$ For children, it is also substantially more likely than for adults that the marginal cost of protecting various rights will fit this pattern of extreme disproportionality when compared to relevant benefits.

Take, for example, vaccines and the right to health as it applies to children. For many life-threatening diseases, the cost of vaccinating children will be extremely low. (Measles, for example, is a leading cause of death among young children, but the vaccine costs just nineteen cents per child. ${ }^{148}$ ) The effectiveness of vaccination will also mean that, for most children, the benefits involved will be extremely high-both when it comes to avoiding pain and suffering, and also prolonging life-expectancy. In most cases, for the state to deny children access to vaccines, therefore, will be to send a clear message that it does not value the inherent dignity of children, as it does for adults.

A similar principle also applies to other forms of preventive health care, such as the kind of access to Nevirapine ordered by the South African Constitutional Court in TAC. ${ }^{149}$ Each patient tested and counseled for HIV clearly added some additional cost to the operation of government health clinics in South Africa. Such additional costs, however, were likely very small relative to the fixed costs in-

147 See Dixon, supra note 102, at 400-01; Sandra Liebenberg, The Value of Human Dignity in Interpreting Socio-Economic Rights, 21 S. Afr. J. Hum. RTs. 1, 22 (2005). Unlike Liebenberg, we do not believe that the denial of any rights-claim that is justified in cost-benefit terms (that is, inherently reasonable and proportionate) will constitute an affront to dignity in this sense. The polycentric nature of socioeconomic rights may mean that, in cases where costs and benefits are relatively evenly balanced, it is reasonable to deny even such reasonable demands, in order to realize more cost-effective protections in other contexts. See Dixon, supra note 102, at 401. The same will not be true, however, in cases of extreme disproportionality.

148 Helen Saxenian, International Aids Vaccine Initiative/Program for Aprropriate Technology in Health, HPV Vaccine Adoption in Developing Countries: Cost and FinANCING Issues 10 (2007), available at http://www.rho.org/files/IAVI_PATH_HPV_ financing.pdf.

149 See Minister of Health v. Treatment Action Campaign (No. 2) 2002 (5) SA 721 (CC) at 765 (S. Afr.). 
volved in establishing a system of testing and counseling. ${ }^{150}$ Nevirapine itself was also being offered to the South African government free of charge at the time of the TAC case. ${ }^{151}$ For this reason, the Court could also be extremely confident in predicting that "where testing and counseling facilities" existed, Nevirapine could be provided by the government "within the available resources of the state." 152

In some cases, preventive interventions by the state may be more expensive, so that an extreme disproportionality principle no longer applies. However, in many of these cases special priority for children's rights may still be justified, under a cost-effectiveness principle, because of the capacity of such rights to prevent a spiraling need for state intervention to protect more and more capabilities.

In prior work on the CA, Wolff and De-Shalit have developed the distinction between ordinary capabilities, and capabilities that are more than usually "fertile" (for other capabilities for the same people, and for the capabilities of other people). ${ }^{153}$ They have also distinguished between standard forms of disadvantage and those forms of disadvantage that are particularly "corrosive" in terms of a CA-because of the likelihood that such disadvantage will cause other forms of capability failure in the future. ${ }^{154}$ It will clearly also be legitimate, under a CA, for the state to focus in the first instance on supporting those forms of capability that are most fertile or eliminating those forms of disadvantage that are most corrosive.

When the state is unable to realize its immediate duty to protect capabilities under a CA, a CA urges choices that promote the maximal realization of everyone's capabilities in the future. By eliminating the most acute forms of corrosive disadvantage in the present, a state also directly increases its ability to meet this goal within the shortest possible time frame. A concern with cost-effectiveness is also itself just one species of this more general point about fertility and corrosiveness: if we can protect particular capabilities now in a way that reduces the need for the state to support related capabilities in the future, in a world of resource constraints we are more likely to achieve the full realization of universal human capabilities in the near term.

Moreover, while the CA holds that determining "fertile" capabilities and corrosive disadvantages is a contextual matter, which may vary with historical and economic circumstances, it is plausible to think

\footnotetext{
150 See id. at 743 para. 49.

151 See id. at 731 para. 11.

152 Id. at 749 para. 73.

153 See Nussbaum, Creating Capabilities, supra note 15, at 44-45; Wolff \& De-Shalit, supra note 23, at 121-22.

154 WolfF \& De-Shalit, supra note 23, at 121.
} 
that the protection of children's capabilities will often be unusually fertile, so that a limited priority for these capabilities will also frequently be justified, given a concern to avoid creating spiraling capabilities costs. ${ }^{155}$ Take children and the right of access to adequate food and nutrition. ${ }^{156}$ For school-aged children, numerous studies show a link between severe hunger and the development of various chronic medical conditions. ${ }^{157}$ In other studies, severe hunger has been associated with heightened forms of stress and mental illness in later life. ${ }^{158}$ Such threats to physical and mental well-being are also direct triggers, under a CA, of further obligations on the part of the state. That is, where to begin with the state was only under a duty to provide adequate nutrition, it will now be under a duty to provide access to nutrition and adequate forms of medical treatment and psychiatric support.

By imposing a special duty on states to combat "malnutrition" for children "through the provision of adequate nutritious foods and clean drinking-water," 159 therefore, instruments such as CROC help reduce potential spiraling costs to state parties of meeting universal obligations to protect individual health, over the long term. A similar analysis also applies to decisions, such as that of the Supreme Court of India, which emphasize the importance of children's access to adequate nutrition by ordering the provision of a nutritious midday meal in all schools ${ }^{160}$ (a policy that had for some time worked well in Kerala and Tamil Nadu). ${ }^{161}$

155 Cf. Nolan, Children's Socio-Economic Rights, supra note 9, at 14-15 (making similar arguments in respect of certain socioeconomic rights for children, though not explicitly in reliance on the language of fertility and corrosiveness).

156 See, e.g., CROC, supra note 7, art. 24(2) (c) (noting the duty of states "[t]o combat disease and malnutrition ... through the provision of adequate nutritious food and clean drinking-water," as part of children's right of access to health care).

157 Linda Weinreb et al., Hunger: Its Impact on Children's Health and Mental Health, 110 Pediatrics 1, 4, tbl.1 (2002).

158 See, e.g., id. at 5 tbl.2.

159 CROC, supra note 7, Art 24(2) (c).

160 See People's Union for Civil Liberties v. Union of India, Writ Petition (Civil) No. 196 of 2001, http://www.righttofoodindia.org/orders/nov28.html (S.C. Nov. 28, 2001) (India).

161 See V.A. Gangadharan, Government of Kerala, Noon Meal Scheme in Kerala: New Management Proposal for the School Lunch Program 12 (2006) ("Kerala is a pioneer in the introduction of the [Noon Meal] scheme in the country and compared to many states, it has been a tremendous success here."), available at http://www.righttofood india.org/data/gangadharan2006keralanoonmealmanagement.doc; RIGHT TO FoOD CAMpaign-Tamil Nadu, Inquiry Report into Accident at Melvalampettai Higher SeconDARY SCHOOL 2 (2006), available at http://www.righttofoodindia.org/data/rtftn06 mdmaccidentenquiry.doc ("The Noon Meal Programme (NMP) has a long history in Tamil Nadu and has become one of the most prestigious programmes of the state government. The Tamil Nadu scheme is the country's largest in terms of the number of beneficiaries covered."). 
A concern to avoid spiraling costs can also be used to explain the special priority given to children's right of access to education under CROC and various national constitutions. Education, as Justice Brennan noted in Plyler v. Doe, "provides the basic tools by which individuals [are able to] lead economically productive lives to the benefit of us all."162 The quality of education individuals receive is also an important predictor of their likelihood of employment, and earnings, later in life. ${ }^{163}$ We know, furthermore, that there are certain critical periods for cognitive development during which educational interventions are especially effective, and after which it may prove difficult or even impossible to make up for lost time. ${ }^{164}$ For the state, this means that giving special priority to children's education can also provide an extremely efficient means of fulfilling its responsibility to provide all individuals with a minimum threshold level of control over their "material environment" —or ability to "seek employment on an equal basis with others." 165

As Justice Powell implicitly noted, in Plyler, if the state invests in a child's basic preschool, primary, and secondary education, in many cases it will have no need to expend further resources in order to ensure that the child is guaranteed a minimum level of economic security and opportunity as an adult. ${ }^{166}$ Conversely, if it does not invest heavily in the education of at-risk children, it will often need to invest substantial resources in order to ensure such children even minimal economic security, as adults, in a way that involves significant unnecessary social costs. ${ }^{167}$ By the time such children reach young adulthood, basic forms of educational intervention will often have little impact on

162 Plyler v. Doe, 457 U.S. 202, 221 (1982).

163 See, e.g., Bureau of the Census, U.S. Dep't of Commerce, Statistical Brief: More Education Means Higher Career Earnings (1994), available at http:// www.census.gov/apsd/www/statbrief/sb94_17.pdf.

164 See James J. Heckman, Skill Formation and the Economics of Investing in Disadvantaged Children, 312 SCIEnCE 1900, 1901 (2006) [hereinafter Heckman, Skill Formation]; James J. Heckman, Op-Ed., Catch 'Em Young, Wall ST. J., Jan. 10, 2006, at A14 [hereinafter Heckman, Catch 'Em Young] ("Once a child falls behind in these fundamental skills, he is likely to remain behind.”); Pedro Carneiro \& James Heckman, Human Capital Policy 5-6, 45-49 (Nat'l Bureau of Econ. Research, Working Paper No. 9495, 2003), available at http:/ /www.ecdgroup.com/pdfs/heckman_article-20_05_2003-17_59_04.pdf.

165 Nussbaum, Creating Capabilities, supra note 15, at 32-34.

166 See Plyler, 405 U.S. at 221; see also Heckman, Skill Formation, supra note 164, at 1901; Heckman, Catch 'Em Young, supra note 164; Carneiro \& Heckman, supra note 164, at 45-53. 167 Justice Powell and Justice Brennan made similar points in their respective opinions in Plyler. See Plyler, 405 U.S. at 241 (Powell, J., concurring) (arguing that the consequence of excluding illegal alien children from the public schools would be to create "within our borders a subclass of illiterate persons many of whom will remain in the State, adding to the problems and costs of both State and National Governments attendant upon unemployment, welfare, and crime"); see also id. at 221 (Brennan. J.) (majority opinion) (noting that denying access to education creates "significant social costs borne by our Nation when select groups are denied the means to absorb the values and skills upon which our social order rests"). 
their predicted earnings. ${ }^{168}$ For the state to guarantee them even minimal economic security, therefore, it will often need to provide far more resource-intensive forms of job-related training, social support, or unemployment insurance. From this perspective, investing in a child's education will thus be a highly cost-effective means by which the state can avoid the spiraling costs associated with needing separately to protect individuals' capacity for control over their material environment.

Alternatively, consider the state's duty to help realize the capacity of each individual to think and reason in an informed and independent way. ${ }^{169}$ One important predictor of an individual's capacity to learn such skills is their level of cognitive ability. ${ }^{170}$ All else equal, those with lower cognitive abilities will place greater demands on the resources of the state, in order to realize the minimum threshold level of this capability. Cognitive abilities themselves, however, are also potentially malleable given appropriately targeted forms of educational intervention. ${ }^{171}$ The earlier such intervention occurs, the more effective it is also likely to be. ${ }^{172}$ From this perspective, the state will also clearly be justified in giving at least some priority to the education rights of children, as compared to adults, or to the education of children with cognitive disabilities or other special needs. ${ }^{173}$ By taking such action, a state can avoid not only the waste of human capital that would result from not developing such children's abilities at a critical juncture, ${ }^{174}$ but also, the need in the future to provide far more costly forms of support aimed at developing certain individuals' cognitive abilities.

168 See Heckman, Skill Formation, supra note 164, at 1901; Heckman, Catch 'Em Young, supra note 164; Carneiro \& Heckman, supra note 164, at 49-53.

169 Nussbaum defines the relevant capability as "[b]eing able to . . . think, and reason-and to do these things in . . . a way informed and cultivated by an adequate education." See Nussbaum, Creating Capabilities, supra note 15, at 33.

170 See Carneiro \& Heckman, supra note 164, at 36 (demonstrating that both cognitive and noncognitive skills play a major role in promoting educational attainment).

171 See, e.g., id. at tbl.6.

172 See James J. Heckman, Lessons from the Bell Curve, 103 J. Pol. Econ. 1091, 1112 (1995); see also Carneiro \& Heckman, supra note 164, at 30.

173 See CROC, supra note 7. In the United States, IDEA gives all children with disabilities rights to an education in accordance with an Individualized Education Plan. Individuals with Disabilities Education Act, 20 U.S.C $\$ \S 1400-82$; see Nussbaum, Frontiers, supra note 15, at 203-11; Nussbaum, The Capabilities of People with Cognitive Disabilities, supra note 18 at 332, 341-45. The cases that prompted IDEA insisted that the state may not shirk its constitutional responsibility to treat these children with equal respect simply because their education is unusually costly. See Smith v. Robinson, 468 U.S. 992, 996 (1984); Pa. Ass'n for Retarded Children v. Pennsylvania, 343 F. Supp. 279, 301-02 (E.D. Pa. 1972).

174 See Heckman, Skill Formation, supra note 164, at 1901-02 \& fig. 2. See generally Prabhat Patnaik, Affirmative Action and the "Efficiency Argument," in EQUALISING Access: AFfirmative Action in Higher Education (Zoya Hasan \& Martha C. Nussbaum eds., forthcoming 2012). 


\section{III \\ Limits AND EXTENSIONS}

It is also important to note, however, that both these principlesof special vulnerability and cost-effectiveness-have clear logical limits from the perspective of a CA.

\section{A. Limits}

When it comes to a vulnerability principle, for example, an important component to a CA, as the Introduction and Part I note, is that it recognizes human frailty and vulnerability as central parts of the human condition for adults as well as for children. Thus, a CA recognizes that parents themselves will often face tragic choices under the CA: if they cannot provide for themselves, as well as their children, they will have to make a tragic choice among competing capabilities. A decent society will find ways to remove the need for parents to make such choices. ${ }^{175}$ Unlike some other approaches to social justice (such as many social contract theories), a CA also insists, in this context, that we think of this responsibility in global, not simply local or national, terms. ${ }^{176}$ For a child's vulnerability to justify special forms of resourcepriority under a CA, therefore, that form of vulnerability must also be one largely unique to the particular child, rather than shared by adults (or parents) in the society more generally. If a reasonable, conscientious parent in a particular society could not be expected to provide a child with access to a particular good because of economic scarcity, a child's vulnerability to deprivation simply will not be the result of the specific incapacity or unwillingness of their parent (or guardian). Rather, their vulnerability will arise as a result of a general economic insecurity that they share with these adults-so that they will also be entitled only to the general forms of protection against deprivation enjoyed by such adults. ${ }^{177}$

In South Africa, the dispute over the scope of children's rights of access to shelter in Grootboom turned on exactly this distinction. ${ }^{178}$ In the High Court, as Part I notes, Judge Davis gave strong priority to

175 See Nussbaum, Creating Capabilities, supra note 15, at 36-39.

176 See Nussbaum, Frontiers, supra note 15, at 274-75. This understanding also conforms to the legal position under many IHR treaties. See, e.g., ICESCR, supra note 6, art. 2(1) (requiring states "to take steps, individually and through international assistance and co-operation, especially economic and technical" to realize the rights set out in the Covenant).

177 See, e.g., supra notes 153-55 and accompanying text.

178 See generally Nolan, Children's Socio-Economic Rights, supra note 9, at 235-36; Linda Stewart, Interpreting and Limiting the Basic Socio-Economic Rights of Children in Cases Where They Overlap with the Socio-Economic Rights of Others, 24 S. Afr. J. Hum. RTs. 472, 473 (2008) (exploring the seeming "overlap of different socio-economic rights (basic and qualified) in cases where the parents and their children claim to be entitled to socio-economic rights"). 
children and their guardians, by requiring that the local authorities provide basic shelter to all the child plaintiffs, where for the remaining adults, he provided only more abstract declaratory relief. The Constitutional Court, by contrast, held that a child's right to "shelter" under Section 28 of the South African Constitution, and the more general right of access to housing under Section 26, should be "read together," and denied any special relief to children. ${ }^{179}$ A clear justification for this finding by the Court (though the Court itself did not cite such a justification) was also that adults generally did not enjoy broad access to shelter of the relevant kind. In the Western Cape area alone, as the Court noted in Grootboom, "[h]undreds of thousands of people ... occupied [only] rudimentary informal settlements providing for minimal shelter, but little else," and were thus in desperate need of housing. ${ }^{180}$ The average parent in the society was thus simply not in a position to provide access to even basic adequate shelter to their children, even when acting with maximum conscientiousness. Because of this, it was also entirely reasonable for the Court to find that Section 28 did not entitle children to any form of special priority in the circumstances.

It is also important to note in this context that the emphasis under a CA is on what the reasonable parent in a society can be expected to do to protect their children's capabilities. It is not enough under a CA to look at what the average parent in a society is willing to do, because in many societies, parents may systematically neglect the protection of certain capabilities for children, particularly girls. ${ }^{181}$ Where social norms define females as less worthy of full human development than males, the CA also insists unequivocally on the equal worth of all human beings and the equal entitlement of all to access relevant capabilities. ${ }^{182}$

This insistence on human equality does not make the CA "Western" or "imperialistic." 183 All nations have difficulty accepting and supporting the full equality of women, and nations that have great practical gaps between male and female have often given very strong

179 Gov't of the Republic of South Africa v. Grootboom, 2001 (1) SA 46 (CC), at 81-82, paras. 74, 76-79 (S. Afr.).

$180 \quad$ Id. at 55 para. 6.

181 Cf. Nolan, Children's Socio-Economic Rights, supra note 9, at 10 ("[S] ome commentators have gone so far as to argue that 'adultism'- the oppression of children by adults - has the same power dimension in children's lives as sexism or racism.").

182 See Nussbaum, Women and Human Development, supra note 15, at 1-11. Thus it is not reasonable under a CA, for example, to deny girl children health care of the same quality that boys would receive, to subject them to differential risks of sexual violence, to exclude them from education, and to restrict their mobility in ways that impede learning and the development of political participation. Id.

See Nussbaum, Creating Capabilities, supra note 15, at 106-07. 
support to an ideal of human equality. ${ }^{184}$ India is an obvious case in point. Discrimination on grounds of both gender and caste-even in basic health care and education-remains extremely common. ${ }^{185}$ And yet the founding ideal of the nation, through the influence of both Gandhi and Ambedkar, is one of full human equality and full human empowerment. ${ }^{186}$ There is nothing at all foreign or colonial about this goal.

When it comes to considerations of cost, or cost-effectiveness, a CA likewise imposes two important limits on the application of such a principle. One such limit is that it be applied with careful attention to notions of fertility and corrosiveness. ${ }^{187}$ Not only are such concepts now integral to a CA, as it has been developed by philosophers, but they also help ensure that, in incorporating attention to considerations of cost, a CA retains its focus on the realization of each and every one of the ten key human capabilities and not simply on more aggregate measures of wealth or well-being. ${ }^{188}$ The reason for this is that, by definition, these notions depend on there being multiple, distinct dimensions to a CA, and they thus highlight the complex goals of a CA, as compared to the more homogenous aims of utilitarian approaches to social justice. ${ }^{189}$

A second important limit to a cost-effectiveness principle under a CA is that it cannot be invoked in societies, such as the United States, where resource constraints do not actually prevent the state from protecting the capabilities of all citizens, up to a basic minimum threshold, so as to violate the equal right of all citizens to protection of their capabilities-even where the realization of particular capabilities may be extremely expensive.

Take the right of children with cognitive disabilities to equal access to an education that can sustain and support the development of capabilities such as practical reason and affiliation. ${ }^{190}$ From the perspective of a CA, it does not matter that it is often extremely expensive to provide education of this kind. Notions of substantive equality mean that, where education is likely to have real benefits for people with cognitive disabilities, and the state resources exist, it is a moral imperative to provide such education-regardless of the expense in-

184 See Nussbaum, Women and Human Development, supra note 15, at 24-25.

185 See Nussbaum, Creating Capabilities, supra note 15, at 5-6; Nussbaum, Women and Human Development, supra note 15, at 16 n.17, 26-28.

186 See Nussbaum, Creating Capabilities, supra note 15, at 66, 105; Nussbaum, Women and Human Development, supra note 15, at 39.

187 See, e.g., Nussbaum, Creating Capabilities, supra note 15, at 44.

188 See, e.g., id. at 47-56 (identifying "aggregat[ion] across lives" as problematic components of GDP and Utilitarian development economic models).

189 See id. at 52; Nussbaum, Constitutions and Capabilities, supra note 3, at 18.

190 See Smith v. Robinson, 468 U.S. 992, 996 (1984); Pa. Ass'n for Retarded Children v. Pennsylvania, 343 F. Supp. 279, 301-02 (E.D. Pa. 1972). 
volved. ${ }^{191}$ The scope of IHR and many constitutional rights in this area are also fully consistent with this understanding.

CROC, for example, requires states parties to ensure that disabled children "ha[ve] effective access to and receive[ ] education, training, health care services, rehabilitation services, preparation for employment and recreation opportunities in a manner conducive to the child's achieving the fullest possible . . . development." 192 Article 24(2) of the Convention on the Rights of Persons with Disabilities likewise requires states to provide "[e]ffective individualized support measures" for persons with disabilities in order to "maximize [their] academic and social development," in the context of the "the right of persons with disabilities to education." 193

At a constitutional level, in Mills v. Board of Education, ${ }^{194}$ the U.S. District Court for the District of Columbia likewise ruled in a manner consistent with a CA. The court held that the exclusion of children with cognitive disabilities from the District of Columbia public schools could not be justified by pointing to the expense involved in educating these children. It is violative of the Due Process Clause to "deny[ ] [children with cognitive disabilities] not just an equal publicly supported education, but all publicly supported education[,] while providing such education to other children." 195

\section{B. Extensions}

Providing these limits are borne in mind, however, we suggest that both principles have the potential to have broad application, well beyond the context of children's rights.

Take a provision such as Section 27(3) of the South African Constitution, which provides that " $[\mathrm{n}] \mathrm{o}$ one may be refused emergency

Cf. Nussbaum, Frontiers, supra note 15, at 202 ("In other words, the purpose of social cooperation is not to gain an advantage; it is to foster the dignity and well-being of each and every citizen. This goal is interpreted to mean that expenditures on poverty, though they may be costly, are required by the very nature of our social commitment." (emphasis added) (footnote omitted)).

192 See CROC, supra note 7, at Art. 23(3).

193 Convention on the Rights of Persons with Disabilities, G.A. Res. 611, U.N. GAOR, 61st Sess., Supp. No. 49, U.N. Doc. A/61/106 (Vol. 60.), at arts. 24(1), 24(2) (e); see also id. at art. 7(1) (guaranteeing the right of children with disabilities "to be provided with disability and age-appropriate assistance" in order to realize the right "to express their views freely on all matters affecting them").

194348 F. Supp 866, 875-76 (1972).

$195 I d$. at 875 . "The Fifth Amendment, which is applicable in the District of Columbia, does not contain an equal protection clause as does the Fourteenth Amendment, which applies only to the states." Bolling v. Sharpe, 347 U.S. 497, 499 (1954). Although "equal protection of the laws" is not always interchangeable with "due process of law" there comes a point at which "discrimination may be so unjustifiable as to be violative of due process." $I d$. There is little doubt that this case would have been resolved in the same manner under the Fourteenth Amendment. See id. at 500. 
medical treatment,"196 or provisions in various national constitutions, including the South African Constitution, limiting the ability of states to evict unlawful occupiers of property. ${ }^{197}$ Such provisions clearly give some form of special priority to particular rights claimants, such as those injured in an accident, or suffering some other kind of medical emergency, or with existing access to informal housing. The more general right to health care and housing in South Africa is simply a right to "access" to health care services ${ }^{198}$ or housing, ${ }^{199}$ which the state must take "reasonable . . . measures" progressively to realize, "within its available resources." 200 Those without existing housing will also generally have far less leverage in negotiating access to secure, formal housing than those with a right to resist eviction. Such priority also clearly makes sense, however, under a principle of extreme disproportionality.

For a person seriously injured in an accident or suffering some kind of temporary medical crisis, the benefits of being admitted to a hospital for treatment are almost infinitely large: such emergency treatment can literally save the person's life. For a state hospital, by contrast, if it has emergency room staff on duty and beds available, the marginal cost of treating such a person will often be very low. ${ }^{201}$ This gap-between marginal benefits, on the one hand, and marginal costs, on the other-will also mean that, in most cases, denying emergency treatment to a person will carry with it a message fraught with dignitary consequences.

If one starts with a concern about cost-effectiveness, it is also quite clear why certain special forms of procedural protection ought to be given to unlawful occupiers. Unlawful occupiers have generally built informal housing structures that have some real economic value. The destruction of such homes, therefore, would involve significant replacement costs for either the individual or the state. Giving individuals warning of their potential eviction can also often help avoid this kind of destruction of economic value: either by allowing them the

196 S. Afr. Const., 1996, ch. 2, § $27(3)$.

197 Id. ch. 2, § 26(3) ("No one may be evicted from their home, or have their home demolished, without an order of court made after considering all the relevant circumstances. No legislation may permit arbitrary evictions.").

198 Id. at ch. 2, § 27(1)(a).

199 Id. at ch.2, § 26(1).

$200 \quad I d$. at ch. $2, \S \S 26(2) ; 27(2)$.

201 Where beds are not available, the risk of cross-infection created by putting such a person on a trolley can mean that the marginal cost is longer in this same category (that is, very low). See Paschim Banga Khet Mazdoor Samity v. State of West Bengal, A.I.R. 1996 S.C. 2426, at 2427-28, If 5 (India). 
opportunity to reach a compromise with the property owner ${ }^{202}$ or by giving them time to move basic building materials and possessions. ${ }^{203}$

Cost-effectiveness concerns can potentially go even further in justifying special protection for the rights of informal housing dwellers, given a concern about spiraling capabilities costs. Housing is linked to a form of capability-namely, control over the material environment-that is particularly fertile for the enjoyment of other capabilities. ${ }^{204}$ Adequate housing is generally a key precondition, for example, for the enjoyment of bodily security; physical health, or protection from the elements; a sense of psychological security; sense of community; and also access to employment. ${ }^{205}$ By protecting an individual's access to such housing, therefore, the state can often indirectly promote a whole range of other key capabilities-including bodily integrity, bodily health, life, emotion, affiliation, and (broader) control over the material environment-whereas if it undermines such access, it can create forms of corrosive disadvantage that call for more and more intensive forms of intervention by the state. ${ }^{206}$

Take the circumstances in Tellis $v$. Bombay, decided by the Supreme Court of India. ${ }^{207}$ The petitioners were pavement-dwellers in Bombay who had come to the city to seek work from areas of high rural unemployment. For most petitioners, as the Supreme Court of India noted, the ability to live on "a pavement or a slum in the vicinity of their place of work" was also essential to their ability to find any kind of work at all in Bombay-even work that simply provided "the means of bare subsistence." ${ }^{08}$ In most cases, if they chose to live further away, the time and expense of commuting to work would simply be prohibitive and thus cause them to lose their job and means of livelihood. ${ }^{209}$ Under a CA, given the duty of the state to ensure a min-

202 See, e.g., Occupiers of 51 Olivia Road, Berea Township, and 197 Main Street, Johannesburg v. City of Johannesburg 2008 (3) SA 208 (CC) at 217 para. 18 (S. Afr.).

203 Cf. Gov't of the Republic of South Africa v. Grootboom 2001 (1) SA 46 (CC), at 84 para. 88 (S. Afr.) (explaining the unreasonableness of state action in which "respondents were evicted a day early and to make matters worse, their possessions and building materials were not merely removed, but destroyed, and burnt").

204 See supra note 37 and accompanying text.

205 See, e.g., Theresa C. Heintze et al., Housing Assistance and Employment: How Far-Reaching Are the Effects of Rental Subsidies?, 80 Soc. Serv. Rev. 635, 663 (2006) (demonstrating that low-income housing subsidies that created long-term housing leader to a greater likelihood of employment and community involvement); supra note 37 and accompanying text.

206 See supra notes 153-55 and accompanying text.

207 Tellis v. Bombay Mun. Corp., (1985) 2 Supp. S.C.R. 51 (India), available at www.escr-net.org/usr_doc/Decision.doc.

$208 I d$. at $62,83$.

$209 I d$. at 83 (noting that petitioners "choose a pavement or a slum in the vicinity of their place of work, the time otherwise taken in commuting and its cost being forbidding for their slender means). 
imum livelihood for all, this would also mean the state assuming responsibility for providing them access to some form of social welfare.

This does not mean, of course, that the state should never be able to evict the occupants of informal housing. On the contrary, sometimes relocating pavement, or slum, dwellers will be essential to the progressive realization of the state's duty to provide access to adequate housing - by allowing the state to upgrade housing within a particular area. ${ }^{210}$ A concern about spiraling capabilities costs will, however, mean when the state relocates people in this way, it will generally be required to provide certain ancillary protections against the risk of corrosive disadvantage- such as transportation allowing people to attend work, or access to new schools. ${ }^{211}$ As cases in South Africa such as Residents of Joe Slovo Community v. Thubelisha Homes ${ }^{212}$ demonstrate, this again creates a form of special priority for the occupants of existing informal housing, relative to those without any form of access to housing. ${ }^{213}$

Special priority of this kind is also arguably justifiable under a CA by reference to a vulnerability principle. The application of such a principle will admittedly be somewhat more complex than a pure costeffectiveness principle in this context because on some level homeless is always the product of legal regulation by the state. By establishing and maintaining a system of private property, the state is in some sense legally responsible for individual economic vulnerability: if adverse economic circumstances or shocks prevent a person from buying or renting land or housing, or using land to engage in acts of basic subsistence, it is the law of property that prevents individuals from simply using such land-without payment-to achieve this end.214 There is, however, an important difference in degree between such cases and cases in which a court makes an order of eviction. The law in cases of eviction is the direct and proximate cause of a person's homelessness; whereas in other cases, it is simply one of many poten-

210 This has been particularly true in South Africa, given the history of segregated housing under apartheid. See, e.g., Vinothan Naidoo, Government Responses to Street Homelessness in South Africa, 27 Dev. S. Afr. 129, 134-36 (2010).

211 Cf. Nussbaum, Creating Capabilities, supra note 15, at 145 ("The fertility of a given capability, and the corrosiveness of a given capability failure, are empirical questions whose answers are likely to vary with time and place and with the particular problems of the disadvantaged group.").

212 Residents of Joe Slovo Cmty. v. Thubelisha Homes 2010 (3) SA 454 (CC) (S. Afr.).

213 See id. at 493 para. 107 (noting that the "traumatic experience[ ]" of relocation was "ameliorated by the State undertaking to provide transport and to ensure that schooling is available to children, and that people . . . can get to work").

214 See Cass R. Sunstein, The Partial Constitution 70-74 (1993); Robert L. Hale, Coercion and Distribution in a Supposedly Non-Coercive State, 38 Pol. SCI. Q. 470, 471-72 (1923). 
tial contributing factors. The two cases also differ in important respects in terms of individual agency.

When it comes to creating informal housing, for example, unlawful occupiers of land often show a great deal of entrepreneurship, hard work, and tenacity in finding, or building, informal housing. In many cases, they also combine this with political mobilization and advocacy in order to gain access to basic services such as running water, garbage collection and basic sewerage. ${ }^{215}$ This is also exactly the kind of individual agency that in the face of true resource (or housing) scarcity the CA values.

While in building such housing, squatters are almost always disobeying the law, they are generally also doing so for good reasonthat is, that they have no realistic other way in which to secure even life-preserving forms of minimal shelter for themselves and their families, over the short- to medium-term. In most cases, given the possibility of their eviction, they are also acting in a way that has only temporary force. In effect, therefore, they are simply increasing the long-term opportunities for the state to fulfill its duty, under a CA, to provide universal access to both fully adequate housing and protection of private property (or control over a person's material environment).

\section{CONCLUSiON}

In several respects, this Article leaves important questions unanswered. For one, the Article specifically avoids taking a final stance, in a number of areas, on a number of "hard cases" involving children's rights.

A very complicated question that we have not fully analyzed, for example, is the right to vote for children. We have argued that the equal dignity of minors does not require giving them an equal right to vote (and thus their case is asymmetrical with the case of adults with cognitive disabilities). But we have not addressed the question whether there might be more instrumental reasons, based upon the need to gather information about children's perceived interests, and upon the need to take account of those interests in planning a future, that might lead to granting older children a right to vote in some limited and specific contexts. ${ }^{216}$

Similarly, in the area of sexuality, we have not addressed the difficult question of how to balance concern for children's physical and economic vulnerability with the need to respect agency. Although we

215 Witness the success of the Joe Slovo community outside of Cape Town in gaining access to running water, portable toilets, electricity and street-numbering from the City of Cape Town. See Slovo, 2010 (3) SA at 467, 472-74, 506, 514, paras. 21-22, 46, 156, 185.

216 See supra notes 75-76 and accompanying text. 
would be opposed to granting young children rights of sexual consent, given their vulnerability to manipulation and abuse, ${ }^{217}$ and recognize that the state must adopt some kind of bright-line rule in this area, we do not take a definite position on what the age of consent ought to be. Nor do we address the question of how, even beyond the age of consent, the special vulnerability of adolescents should be recognized by rape law, in cases involving teachers or other figures in positions of authority. Current legal thinking about adult women has recognized that respect for sexual agency is not incompatible with recognizing the extortionate character of some requests for sex in situations of asymmetrical power, and this problem is surely more acute when the less powerful person is a child. ${ }^{218}$

In this area, as in others, we thus leave a significant amount to be fleshed by national constitutional and legislative developments. It is a general feature of the CA that central entitlements ought to be stated in rather general and abstract terms, precisely in order to leave room for the further specification of such entitlements in the light of a nation's specific history and circumstances. ${ }^{219}$ When we are concerned with children, as with adult women, we may need to look more critically at local customs and norms-because we are dealing with a class of human beings that has too often been considered instrumentally, as mere extensions of the will and goals of someone else, rather than as ends in their own right. ${ }^{220}$ The need still remains, however, to leave space for appropriate forms of democratic deliberation about the precise content to be given to particular capabilities (or rights), in light of relevant national circumstances.

When it comes to questions of special priority more generally, we have likewise mapped out principles that, we hope, can serve as a useful beginning for thinking about such issues, by marking some paths as unpromising or even deeply defective (the "innocence" idea), and identifying more fruitful avenues of justification. Again, however, we have left important details of these questions to be fleshed out in different contexts. In addition, we have suggested that the very issue of special priority should remind us of the inherently tragic nature of

217 See Neerosh Mudaly \& Chris Goddard, The Ethics of Involving Children Who Have Been Abused in Child Abuse Research, 17 InT'L J. Child. RTs. 261, 263 (2009) (noting that children's vulnerability is increased by their developmental needs, dependence on adults, "extrinsic social, cultural and environmental factors (which may include abuse) and intrinsic factors which are inherent in the child (such as cognitive, emotional, sensory deficiencies, physical defects and health issues)" (internal citation omitted)).

218 See generally Stephen J. Schulhofer, Unwanted Sex: The Culture of Intimidation AND The FAILURe OF Law 168-205 (1998) (discussing the potential problems and consequences arising from sexual relationships characterized by asymmetrical power as with supervisors and subordinates or teachers and students).

219 See Nussbaum, Creating Capabilities, supra note 15, at 108-09.

220 See supra note 135 and accompanying text. 
certain choices under a CA. Tragic situations may require us to consider what to do in the immediate situation, but they also make us see that the situation is profoundly defective, because, if we have analyzed the options correctly, minimal justice cannot be achieved, and people must be denied what they have a right to have. ${ }^{221}$ And the appeal to special priority for children, we have suggested, should not be permitted to obscure this fact.

Above all, we hope to have shown that a focus on capabilities and the intellectual architecture of the CA provides a useful framework for the exploration of these urgently important issues. We now see that children's rights are, in fact, a "fourth frontier of justice" added to the three areas already theorized by Nussbaum (rights of people with disabilities, rights across national boundaries, rights of nonhuman animals): ${ }^{222}$ that is, they are rights that are not adequately theorized by existing social contract approaches, because such approaches, assuming a rough equality of physical and mental powers among the contracting parties, are not well equipped to theorize entitlements in areas in which great differences of power exist. The special vulnerability of children means that they are not the "free, equal, and independent" 223 agents of the social contract model. In their case as in the three others mentioned, unusual vulnerability and powerlessness demand a new approach to basic rights. The CA provides that approach.

221 See Nussbaum, Creating Capabilities, supra note 15, at 36-38; Nussbaum, The Costs of Tragedy, supra note 27, at 187-92.

222 See Nussbaum, Frontiers, supra note 15, at 14-22.

223 Locke, supra note 60, § 95. 
Readers with comments may address them to:

\section{Professor Rosalind Dixon}

University of Chicago Law School

1111 East 60th Street

Chicago, IL 60637

Dixon@uchicago.edu 


\section{The University of Chicago Law School Public Law and Legal Theory Working Paper Series}

For a listing of papers 1-345 please go to http://www.law.uchicago.edu/publications/papers/publiclaw.

346. Rosalind Dixon and Richard Holden, Constitutional Amendment Rules: The Denominator Problem, May 2011

347. Rosalind Dixon, Constitutional Amendment Rules: A Comparative Perspective, May 2011

348. Rosalind Dixon, Weak-Form Judicial Review and American Exceptionalism, May 2011

349. Rosalind Dixon, Transnational Constitutionalism and Unconstitutional Constitutional Amendments, May 2011

350. Adam B. Cox and Richard T. Holden, Reconsidering Racial and Partisan Gerrymandering, May 2011

351. Brian Leiter, The Circumstances of Civility, May 2011

352. Brian Leiter, Naturalized Jurisprucence and American Legal Realism Revisited, May 2011

353. Lee Anne Fennell, Property and Precaution, June 2011

354. Alon Harel and Ariel Porat, Commensurability and Agency: Two Yet-to-Be-Met Challenges for Law and Economics, June 2011

355. Bernard E. Harcourt, Radical Throught from Marx, Nietzsche, and Freud, through Foucault, to the Present: Comments on Steven Lukes' "In Defense of False Consciousness,” June 2011

356. Alison L. LaCroix, Rhetoric and Reality in Early American Legal History: A Reply to Gordon Wood, July 2011

357. Martha C. Nussbaum, Teaching Patriotism: Love and Critical Reform, July 2011

358. Shai Dothan, Judicial Tactics in the European Court of Human Rights, August 2011

359. Jonathan S. Masur and Eric A. Posner, Regulation, Unemployment, and Cost-Benefit Analysis, August, 2011

360. Adam B. Cox and Eric A. Posner, Delegation in Immigration Law, September 2011

361. José Antonio Cheibub, Zahcary Elkins, and Tom Ginsburg, Latin American Presidentialism in Comparative and Historical Perspective, September 2011

362. Tom Ginsburg and Rosalind Dixon, Comparative Constitutional Law: Introduction, September 2011

363. Eric A. Posner, Deference to the Executive in the United States after 9/11: Congress, the Courts, and the Office of Legal Counsel, September 2011

364. Adam M. Samaha, Regulation for the Sake of Appearance, October 2011

365. Ward Farnsworth, Dustin Guzior and Anup Malani, Implicit Bias in Legal Interpretation, October 2011

366. Scott A. Baker and Anup Malani, Does Accuracy Improve the Information Value of Trials? October 2011

367. Anup Malani, Oliver Bembom, and Mark van der Laan, Improving the FDA Approval Process, October 2011

368. Adam M. Samaha, Talk about Talking about Constitutional Law, October 2011

369. Eric A. Posner, Some Skeptical Comments on Beth Simmons’s Mobilizing for Human Rights, November 2011

370. Stephen J. Choi, Mitu Gulati and Eric A. Posner, Political Risk and Sovereign Debt Contracts, November 2011

371. $\quad$ Lee Fennell, Lumpy Property, January 2012

372. Jonathan Jackson, Aziz Huq, Ben Bradford and Tom R. Tyler, Going Outside the Law: The Role of the State in Shaping Attitudes to Private Acts of Violence, January 2012 
373. Aziz Z. Huq, Private Religious Discrimination, National Security, and the First Amendment, January 2012

374. Aziz S. Huq, Preserving Political Speech from Ourselves and Others, January 2012

375. Ariel Porat and Eric A. Posner, Aggregation and Law, January 2012

376. Bernard E.Harcourt, On the American Paradox of Laissez Faire and Mass Incarceration, March, 2012

377. Bernard E. Harcourt, The Politics of Incivility, March 2012

378. Bernard E. Harcourt, Fantasies and Illusions: On Liberty, Order, and Free Markets, March 2012

379. Saul Levmore and Ariel Porat, Asymmetries and Incentives in Evidence Production, March 2012

380. Aziz Huq, Forum Choice for Terrorism Suspects, March 2012

381. Lee Anne Fennell, Picturing Takings, April 2012

382. Eric A. Posner and E. Glen Weyl, An FDA for Financial Innovation: Applying the Insurable Interest Doctrine to 21st Century Financial Markets, April 2012

383. David Fagundes and Jonathan S. Masur, Costly Intellectual Property, April 2012

384. Rosalind Dixon and Martha C. Nussbaum, Children's Rights and a Capabilities Approach: The Question of Special Priority, May 2012 